\author{
Marquette University \\ e-Publications@Marquette
}

7-2017

\title{
Reactivity of (1-methoxycarbonylpentadienyl)iron(1+) cations with hydride, methyl, and nitrogen nucleophiles
}

\author{
Yuzhi Ma \\ Marquette University \\ Young K. Yun \\ Marquette University \\ Julie L. Wondergem \\ Marquette University \\ Anobick Sar \\ Marquette University \\ Jayapal Reddy Gone \\ Marquette University
}

See next page for additional authors

Follow this and additional works at: https://epublications.marquette.edu/chem_fac

Part of the Chemistry Commons

\section{Recommended Citation}

Ma, Yuzhi; Yun, Young K.; Wondergem, Julie L.; Sar, Anobick; Gone, Jayapal Reddy; Lindeman, Sergey V.; and Donaldson, William, "Reactivity of (1-methoxycarbonylpentadienyl)iron(1+) cations with hydride, methyl, and nitrogen nucleophiles" (2017). Chemistry Faculty Research and Publications. 804.

https://epublications.marquette.edu/chem_fac/804 


\section{Authors}

Yuzhi Ma, Young K. Yun, Julie L. Wondergem, Anobick Sar, Jayapal Reddy Gone, Sergey V. Lindeman, and William Donaldson 
Marquette University

e-Publications@Marquette

\section{Chemistry Faculty Research and Publications/College of Arts and Sciences}

This paper is NOT THE PUBLISHED VERSION; but the author's final, peer-reviewed manuscript. The published version may be accessed by following the link in the citation below.

Tetrahedron, Vol. 73, No. 30 (July 27, 2017): 4493-4500. DOI. This article is (C) Elsevier and permission has been granted for this version to appear in e-Publications@Marquette. Elsevier does not grant permission for this article to be further copied/distributed or hosted elsewhere without the express permission from Elsevier.

\section{Reactivity of (1-Methoxycarbonylpentadienyl)Iron(1+) Cations with Hydride, Methyl, and Nitrogen Nucleophiles}

\section{Yuzhi Ma}

Department of Chemistry, Marquette University, Milwaukee, WI Young K. Yun

Department of Chemistry, Marquette University, Milwaukee, WI Julie Wondergem (nee Lukesh)

Department of Chemistry, Marquette University, Milwaukee, WI Anobick Sar Department of Chemistry, Marquette University, Milwaukee, WI Jayapal Reddy Gone

Department of Chemistry, Marquette University, Milwaukee, WI Sergey Lindeman

Department of Chemistry, Marquette University, Milwaukee, WI William A. Donaldson

Department of Chemistry, Marquette University, Milwaukee, WI 


\section{Abstract}

The reaction of tricarbonyl and (dicarbonyl)triphenylphosphine (1-methoxycarbonylpentadientyl)iron(1+) cations $\mathbf{7}$ and $\mathbf{8}$ with methyl lithium, $\mathrm{NaBH}_{3} \mathrm{CN}$, or potassium phthalimide affords (pentenediyl)iron complexes $\mathbf{9 a - c}$ and $\mathbf{1 1 a}-\mathbf{b}$, while reaction with dimethylcuprate, gave (E,Z-diene)iron complexes $\mathbf{1 0}$ and 12. Oxidatively induced-reductive elimination of 9a-c gave vinylcyclopropanecarboxylates $17 \mathbf{a}$-c. The optically active vinylcyclopropane (+)-17a, prepared from (1S)-7, undergoes olefin cross-metathesis with excess (+)-18 to yield (+)-19, a C9-C16 synthon for the antifungal agent ambruticin. Alternatively reaction of 7 with methanesulfonamide or trimethylsilylazide gave (E,E-diene)iron complexes $14 \mathbf{d}$ and $\mathbf{e}$. Huisgen [3 +2$]$ cyclization of the (azidodienyl)iron complex 14e with alkynes afforded triazoles 25a-e.

\section{Graphical abstract}
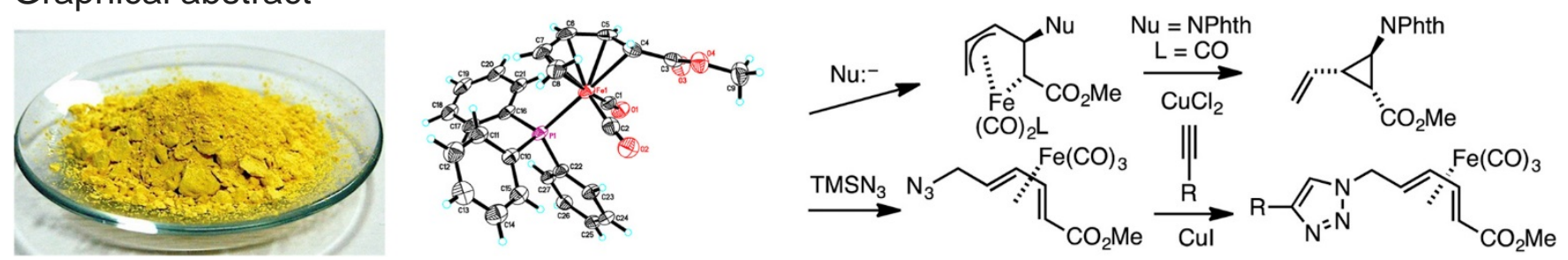

Keywords

Dienyl-iron cations, Nucleophilic addition, Vinylcyclopropanes, Click chemistry

\section{Introduction}

Acyclic (pentadienyl)iron(1+) cations are versatile precursors for organic synthesis, due to the wide variety of structural motifs which may be produced upon nucleophilic addition (Scheme 1). 1 While NMR spectra for most cations 1 are indicative of the " $U$ " or cisoid structure in solution, it is generally believed that the " $\mathrm{S}$ " or transoid form does exist in an equilibrium with the more stable "U" form (Scheme 1). 1 The spectroscopic detection of a transoid structure has only been reported for a single sterically biased case. 2 Nucleophilic attack on the "U" structure may proceed via attack at one of the pentadienyl termini to afford cis-diene complexes 2 (path A), or with weak nucleophiles such as water, amines and electron-rich aromatics, via the lessstable but more reactive " $\mathrm{S}$ " form to generate trans-diene complexes (path B). For certain combinations of nucleophiles and cations, attack occurs at an internal carbon of the dienyl ligand to afford (3-pentene-1,5-diyl)iron complexes 4 (path C). Stable complexes 4, which possess an electron withdrawing substituent at the $\sigma$-bound (C1) carbon, may be decomposed under oxidative conditions to afford vinylcyclopropanes. Alternatively, unstable complexes 4 are known to afford 5-substituted-2-cyclohexenones $\mathbf{6}$ via cyclocarbonylation. 


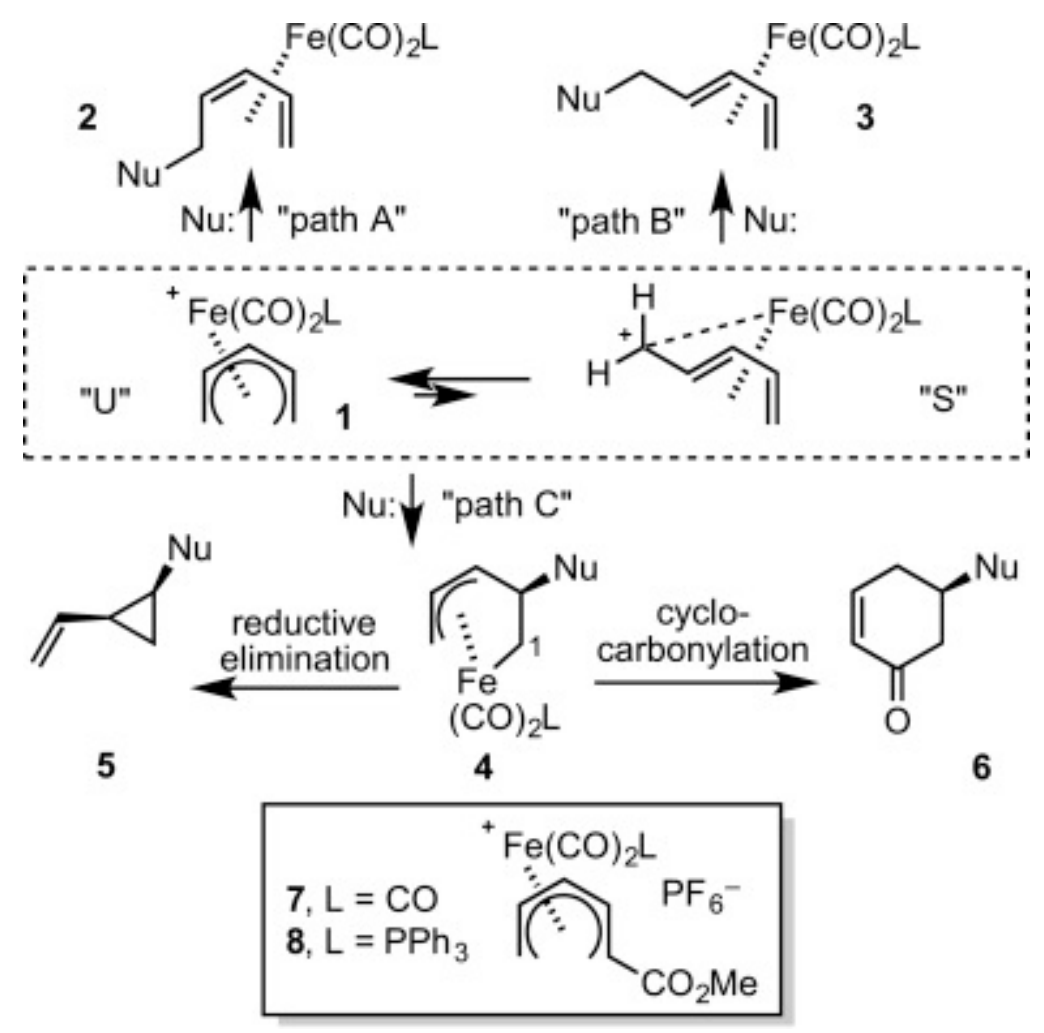

Scheme 1.7 and $\mathbf{8}$ with non-carbon nucleophiles. 6 We herein report on the reactivity of these

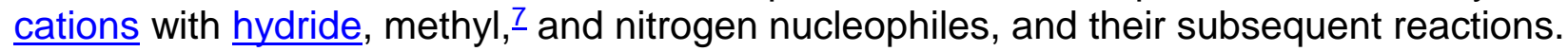

The reactivity of (1-methoxycarbonylpentadienyl)iron(1+) cations $\mathbf{7}$ and $\mathbf{8}$ with carbon nucleophiles is observed to proceed via all three pathways. $, 4, \underline{5}$ This reactivity has been utilized in the synthesis of methyl 5-hydroxyeicosatetraenoate (5-HETE), $\underline{\text { 3a }}$ iron containing HETE analogs,,$\underline{3 \mathrm{C}}$ and the C7-24 segments of macrolactin A, $\underline{3 \mathrm{~b}}$ (path A), and 2-(2'carboxycyclopropyl)-glycines, $\underline{5 c}$ bicyclopropanes, $\underline{5 h}$ and dysibetaine $\mathrm{CPa} \underline{5 i}$ (path $\mathrm{C}$ ). There are fewer examples of the reaction of (dienyl)iron cations.

\section{Results and discussion표}

The (1-methoxycarbonylpentadienyl)iron(1+) cations $( \pm)-7$ and ( \pm )-8 were prepared by literature methods. $3(\mathrm{a}), \underline{5(\mathrm{~b})}$ Cationic complex ( \pm )-8 was isolated as an amorphous solid. Recrystallization from acetone/diethyl ether gave yellow block crystals that were characterized by X-ray diffraction analysis (Fig. 1). .9 The structure of 8 revealed that the triphenylphosphine ligand occupies the basal site anti to the methoxycarbonyl substitutent on the pentadienyl ligand. This relative orientation of the $\mathrm{PPh}_{3}$ ligand, in solution, was previously proposed on the basis of the upfield shifts of $\mathrm{H}-7$ and $\mathrm{H}-8$ exo (numbering in Fig. 1 ) compared to those for $7 . \underline{5 b}$ As anticipated, the Fe-CO bond distances (Table 1) are shorter (1.784-1.812 $\AA$ ) and the carbonyl C-O distances (1.133-1.142 $\AA$ ) for 8 compared to those observed in the crystal structure of $7(\mathrm{Fe}-\mathrm{CO}=1.835-1.837 \AA ; \mathrm{FeC}-\mathrm{O}=1.121-1.137 \AA) .3 \mathrm{c} / \mathrm{n}$ contrast, the $\mathrm{C} 4-\mathrm{C} 5$, 
$\mathrm{C} 5-\mathrm{C} 6$ and $\mathrm{C} 6-\mathrm{C} 7$ distances within the pentadienyl ligand and the iron-to-pentadienyl distances $\mathrm{Fe}-\mathrm{C} 4, \mathrm{Fe}-\mathrm{C} 5$ and.

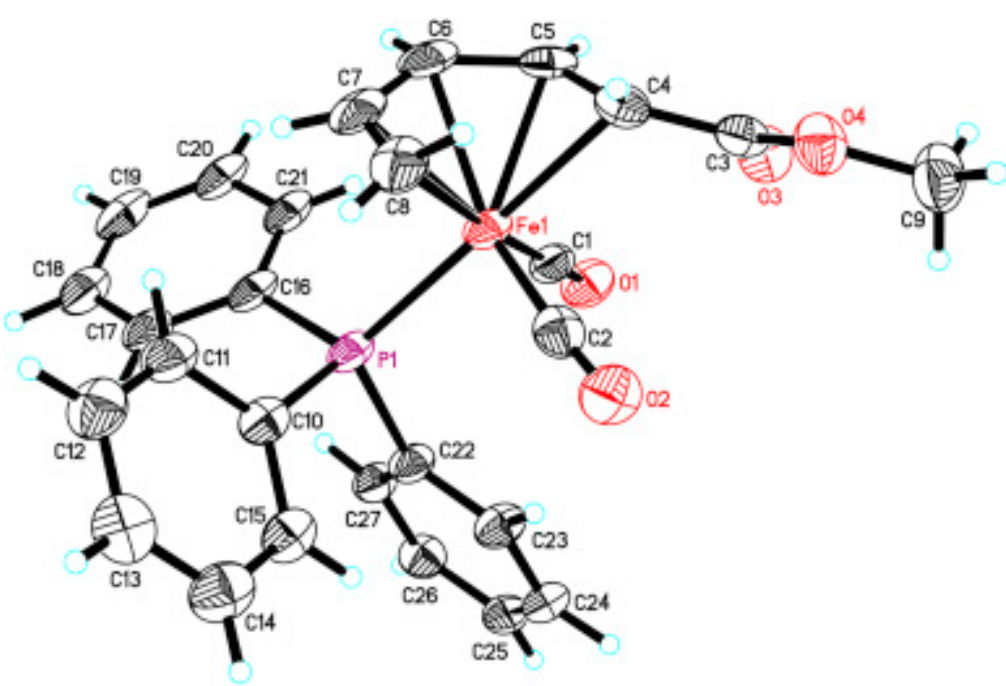

Fig. 1. ORTEP of 8 ( $\mathrm{PF}_{6}{ }^{-}$counterion and solvent molecule omitted for clarity).

Table 1. Bond lengths $(\AA)$ for (pentadienyl)iron cations $\mathbf{7}$ and $\mathbf{8}$ (atom numbering corresponds to structure in Fig. 1).

Bond

$\mathrm{Fe}-\mathrm{C} 1$

$\mathrm{Fe} \_\mathrm{C} 2$

$\mathrm{C} 1$-O1

$\mathrm{C} 2 \_\mathrm{O} 2$

$\mathrm{Fe} \_\mathrm{C} 4$

$\mathrm{Fe} \_\mathrm{C} 5$

$\mathrm{Fe}$ _C6

$\mathrm{Fe} \_\mathrm{C} 7$

$\mathrm{Fe}$ _C8

C4_C5

C5_C6

C6_C7

C7_C8
7 (ref. $\underline{3 c}$ )

1.835(7)

1.837(6)

1.137(8)

1.121(7)

2.168(7)

2.114(7)

2.129(7)

2.141(6)

2.207(7)

1.402(9)

1.418(9)

1.417(9)

1.419(10)
8 (this work)

1.812(5)

1.784(5)

1.133(6)

1.142(6)

2.177(5)

2.101(5)

2.128(5)

2.102(5)

2.165(5)

1.404(7)

1.408(8)

1.417(8)

1.395(8)

$\mathrm{Fe}-\mathrm{C} 6$ for $\mathbf{7}$ and $\mathbf{8}$ are relatively similar, while the $\mathrm{C}-7-\mathrm{C} 8, \mathrm{Fe} \_\mathrm{C} 7$ and $\mathrm{Fe} \_\mathrm{C} 8$ distances $(1.395 \AA, 2.102 \AA$ and $2.165 \AA)$ are slightly shorter for 8, compared to those for 7 (1.419 $\AA$, $2.141 \AA$ and $2.207 \AA$ ). 
We have previously reported ${ }^{7}$ that addition of a solution of methyllithium in ether to a solution of 7 in dichloromethane gave predominantly the pentendiyl complex $9 \mathbf{a}$ along with variable

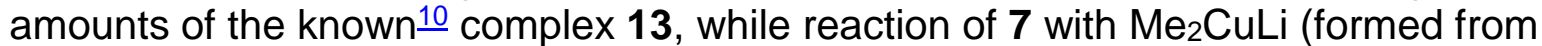
$\mathrm{MeLi} / \mathrm{CuBr}$ ) gave primarily the $E, Z$-diene complexes 10a (Scheme 2, Table 2). The reactions of 7 with $\mathrm{Me}_{3} \mathrm{Al}$ or $\mathrm{MeTi}(i-\mathrm{PrO})_{3}$ were less selective and gave mixtures of 9a and 10a. Reaction of 8 with MeLi or with $\mathrm{Me}_{2} \mathrm{CuLi}$ gave predominantly pentenediyl complex 11a or diene complex 12a. The reaction of 7 with $\mathrm{NaBH}_{3} \mathrm{CN}$ gave a separable mixture of pentenediyl complex $9 \mathbf{b}$ and E,Z-diene complex $10 \mathbf{b}$. Use of $\mathrm{LiAlH}(t-B u O)_{3}$ instead of $\mathrm{NaBH}_{3} \mathrm{CN}$ gave lower yields of $\mathbf{9 b}$. In a similar fashion, reaction of $\mathbf{8}$ with $\mathrm{NaBH}_{3} \mathrm{CN}$ gave predominantly pentenediyl complex 11b. Finally, reaction of 7 with KNPhth, $\mathrm{MeSO}_{2} \mathrm{NH}_{2}$ or $\mathrm{TMSN}_{3}$ gave pentendiyl complex $9 \mathrm{c}$ or $E, E$ diene complexes 14d or 14e.

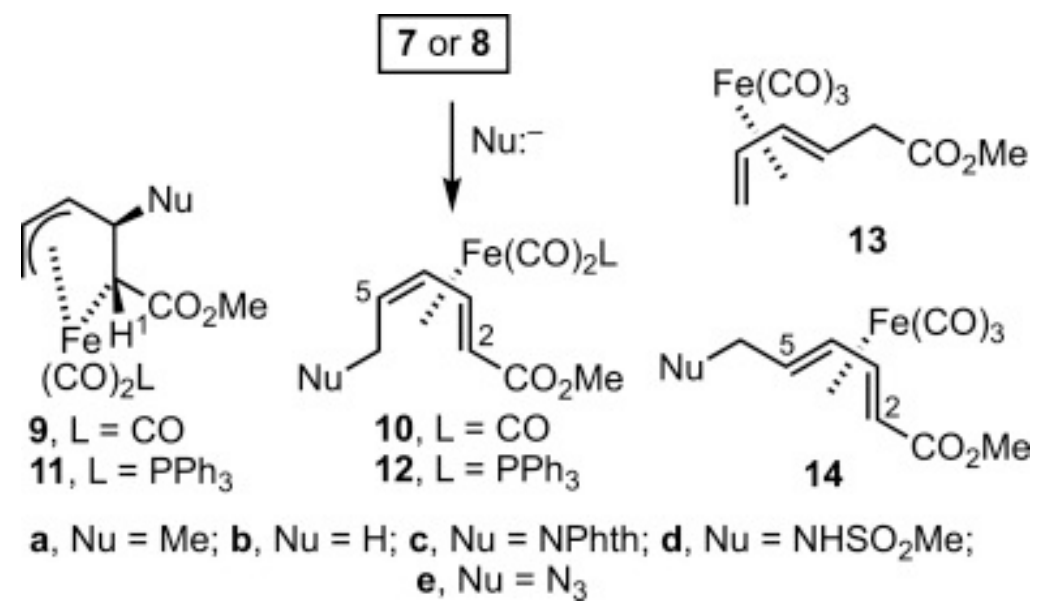

Scheme 2. Nucleophilic addition to (1-methoxypentadienyl)iron cations.

Table 2. Nucleophilic addition to (1-methoxycarbonylpenta-dienyl)iron cations.

Reagents

$7 \mathrm{MeLi} \underline{\mathrm{c}}$

$7 \mathrm{MeLi} / \mathrm{CuBr} \_\mathrm{SMe}_{2} \underline{\mathrm{d}}$

$7 \mathrm{Me}_{3} \mathrm{Al}$ 比

$7 \mathrm{MeLi} / \mathrm{TiCl}(i-\mathrm{PrO})_{3} \underline{\mathrm{c}}$

$8 \mathrm{MeLi} \underline{\mathrm{c}}$

$8 \mathrm{MeLi} / \mathrm{CuBr} \_\mathrm{SMe}_{2} \underline{\mathrm{d}}$

$7 \mathrm{NaBH}_{3} \mathrm{CN}^{\mathrm{f}}$

$7 \mathrm{Lil} / \mathrm{LiAlH}(t-\mathrm{BuO})_{3}{ }^{\mathrm{f}}$

$8 \mathrm{NaBH}_{3} \mathrm{CN} \mathfrak{f}$

$7 \mathrm{~K}^{+-N P h t h}{ }^{\mathrm{g}}$

$7 \mathrm{H}_{2} \mathrm{NSO}_{2} \mathrm{Me}^{-}$

$7 \mathrm{TMSN}_{3}{ }^{\mathrm{h}}$
$\mathrm{Nu}$

Product(s)

Me

Me

$\mathrm{Me}$

Me

$\mathrm{Me}$

$\mathrm{Me}$

$\mathrm{H}$

$\mathrm{H}$

$\mathrm{H}$

NPhth

NHMs

$\mathrm{N}_{3}$

9a $(46-71 \%)+13(0-25 \%)^{\underline{a}}$

$10 a+9 a(14: 1,58 \%)$ a

$10 a+9 a(3: 1,59 \%)^{\underline{b}}$

$10 a+9 a(2: 1,37 \%)^{\underline{b}}$

$11 \mathbf{a}(66 \%)+12 a(2 \%)^{\underline{b}}$

12a $(56 \%)^{\underline{b}}$

$9 b(78 \%)+10 b(12 \%)^{\underline{b}}$

9b $(31 \%)^{\underline{b}}$

11b $(87 \%)+12 b(5 \%)^{\underline{b}}$

9c $(62 \%)^{\underline{b}}$

14d $(98 \%)^{\underline{b}}$

$14 \mathrm{e}(56 \%)^{\underline{b}}$ 
a Reported in preliminary communication (ref. $\underline{7}$ ).

b This work.

c $\mathrm{CH}_{2} \mathrm{Cl}_{2} /-78^{\circ} \mathrm{C}$.

d THF-Et $2 \mathrm{O}(3: 1) /-78^{\circ} \mathrm{C}$.

e $\mathrm{CH}_{2} \mathrm{Cl}_{2} /-30{ }^{\circ} \mathrm{C}$.

f THF/ $/{ }^{\circ} \mathrm{C}$.

$\mathrm{g} \mathrm{CH}_{3} \mathrm{NO}_{2} / 23^{\circ} \mathrm{C}$.

h $\mathrm{CH}_{2} \mathrm{Cl}_{2} / 23^{\circ} \mathrm{C}$.

The structures of the products were assigned on the basis of their NMR spectral data. In particular for 9a-c the presence of three metal carbonyl signals in their ${ }^{13} \mathrm{C}$ NMR spectra (ca. $\delta$ 211-203 ppm) is characteristic of (pentenediyl) $\mathrm{Fe}(\mathrm{CO})_{3}$ complexes, while the upfield signals in the ${ }^{1} \mathrm{H}$ NMR spectra of $\mathbf{9 a - b}$ and $\mathbf{1 1 a}-\mathbf{b}$ (ca. $\delta 0.0-0.17 \mathrm{ppm}$ ) are consistent with the hydrogen attached to the pentenediyl carbon $\sigma$-bonded to iron (i.e. $\mathrm{H}^{1}$ of structure in Scheme 2).5(b), 5(c), 5(i) For (E,Z-diene)Fe(CO) 3 complexes 10a-b signals at ca. $\delta 92$ and 85-87 ppm in their ${ }^{13} \mathrm{C}$ NMR and at ca. $\delta 6.0$ and $5.3 \mathrm{ppm}$ in their ${ }^{1} \mathrm{H}$ NMR spectra are characteristic of $\mathrm{C} 3$ and $\mathrm{C} 4$ and their attached hydrogens respectively.3(a), 3(b) For the corresponding (E,Zdiene) $\mathrm{Fe}(\mathrm{CO})_{1} \mathrm{PPh}_{3}$ complex 12a, the signals for $\mathrm{H} 3$ and $\mathrm{H} 4$ appear at $\delta 5.87$ and $4.28 \mathrm{ppm}$; shifted upfield (compared to 10a-b) due to the anisotropic effect of the triphenylphosphine ligand. $\frac{3 \mathrm{~b} 5 \mathrm{~b}}{}$ Finally, for $\left(E, E\right.$-diene) $\mathrm{Fe}(\mathrm{CO})_{3}$ complexes $14 \mathrm{~d}$-e signals at ca. $\delta 86$ and $85 \mathrm{ppm}$ in their ${ }^{13} \mathrm{C}$ NMR and at ca. $\delta 5.85$ and 5.35 ppm in their ${ }^{1} \mathrm{H}$ NMR spectra are characteristic of $\mathrm{C} 3$ and $\mathrm{C} 4$ and their attached hydrogens respectively. 4

There appears to be little difference between the tricarbonyl-ligated and (dicarbonyl)triphenylphosphine-ligated cations ( $\mathbf{7}$ and $\mathbf{8}$ respectively) in the regioselectivity for addition of methyl lithium or dimethylcuprate. The formation of the regioisomeric (pentenediyl) or (diene) products may be rationalized by initial single electron transfer from either methyl reagent to form a transient (pentadienyl)iron radical and a methyl-metal radical (Scheme 3). Single electron transfer reactions to (pentadienyl)iron cations have previously been reported by Kochi. $\stackrel{11}{ \pm}$ For methyllithium, collapse of the radical pair occurs via $\mathrm{C}-\mathrm{C}$ bond formation at the internal dienyl carbon. Alternatively, for methylcuprate, collapse of the radical pair occurs at the less sterically hindered terminal carbon. If the radical pair escapes the solvent cage, then a second single electron transfer can occur to afford the pentadienyl anion 15. Aqueous work-up of the reaction mixture gives the protonated product 13 .

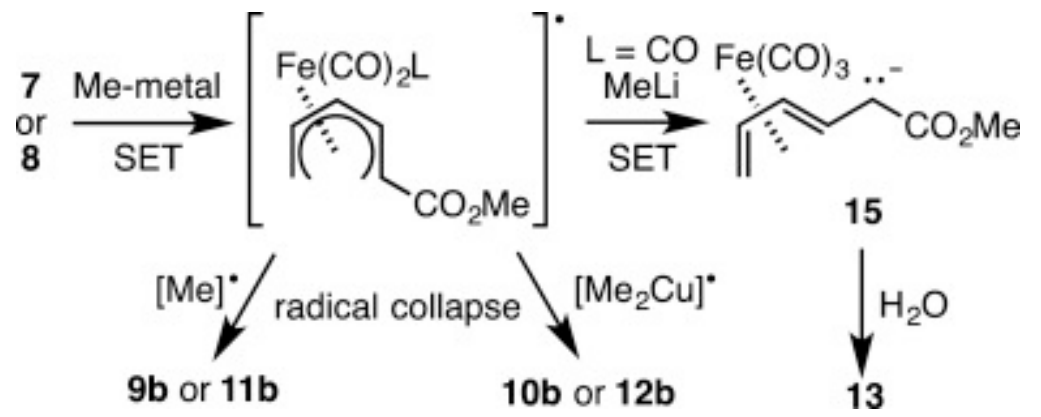

Scheme 3. Mechanism for addition of methyl nucleophiles. 
While the regioselectivity observed for hydride or phthalimide anion addition to 7 (i.e. at C-2) mirrors that previously observed for stabilized carbon nucleophiles, $\underline{5(b)}, \underline{5(c)}, \underline{12}$ it is different compared to that for addition of these nucleophiles to the (1-ethoxycarbonyl-2-

methylpentadienyl) $\mathrm{Fe}(\mathrm{CO}) 3^{+}$cation 16 (eqn. (1)). $\underline{13}$ In the latter case, addition is observed to proceed at the C-5 pentadienyl carbon. The difference in regioselectivity can be attributed to the steric hindrance of the C-2 methyl group in $\mathbf{1 6}$ which is not present in cations $\mathbf{7}$ and $\mathbf{8}$.

The oxidatively induced-reductive elimination of (pentenediyl)iron complexes $( \pm)-9 \mathrm{a}$ with ammonium cerium nitrate [CAN] gave the vinylcyclopropane carboxylate $( \pm)-17 a$ (Scheme 4). The structure of 17a was assigned based on its spectral data. In particular, signals at $\delta 2.14$ (ddd), 1.73-1.60 (m) and $1.45(\mathrm{dd})$ ppm are assigned to $\mathrm{H}-3, \mathrm{H}-2$ and $\mathrm{H}-1$ of the cyclopropane respectively. Furthermore, the large coupling between $\mathrm{H}-2$ and $\mathrm{H}-3(9.4 \mathrm{~Hz})$ indicates a cis relationship, while smaller couplings between $\mathrm{H}-1$ and $\mathrm{H}-2$, and between $\mathrm{H}-1$ and $\mathrm{H}-3$ (ca. $4.5 \mathrm{~Hz}$ each) indicate a trans relationship. In a similar fashion decomplexation of (-)-9a (prepared from (1S)-7a) gave (+)-17a (56\%). Ru-catalyzed cross-metathesis of (+)-17a with $(+)-\mathbf{1 8}^{14}$ (9 equiv.) catalyzed by Grubbs' 2nd generation catalyst gave (+)-19 as a 6:1 mixture of $E$ - and $Z$-stereoisomers. The NMR spectral data for (+)-19 was similar to that reported for (+)-20, a C9-C16 intermediate in Hanessian's synthesis of ambruticin (21). $\underline{\underline{15}}$

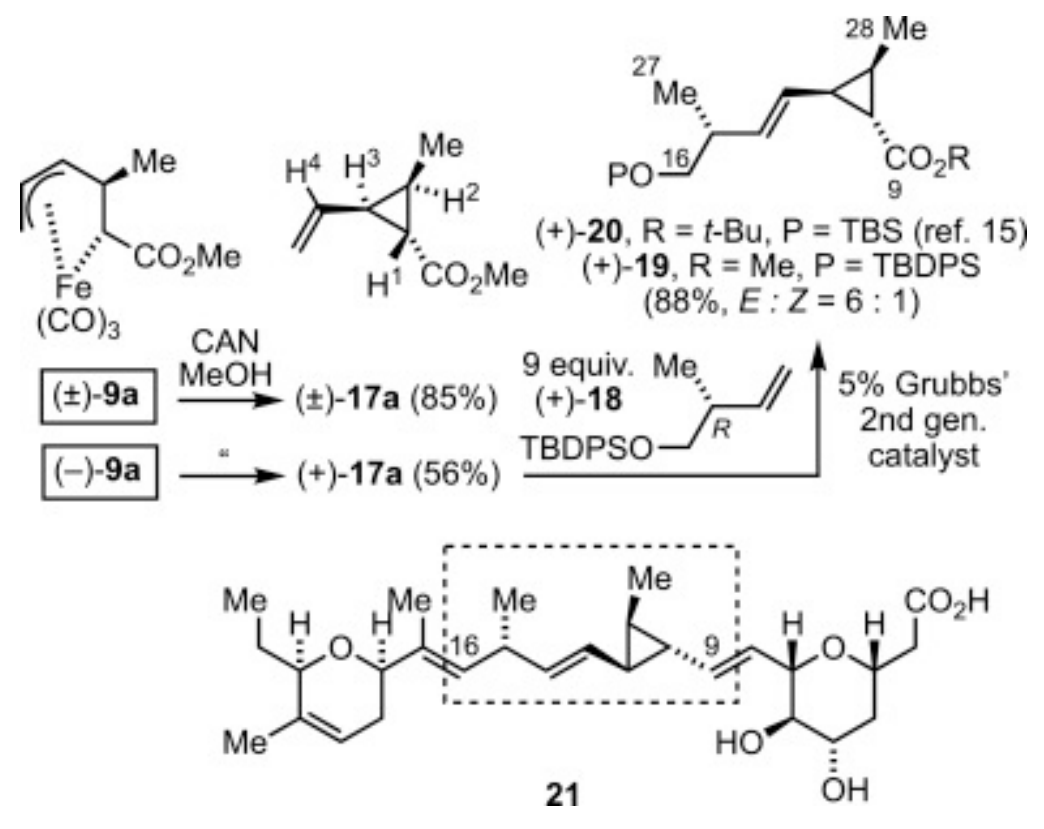

Scheme 4. Oxidative decomplexation of $9 \mathbf{a}$ and further transformation into a C9_C16 synthon for ambruticin.

Oxidative decomplexation of $\mathbf{9 b}$ with CAN gave the vinylcyclopropane carboxylate $\mathbf{1 7 b}$ (Scheme 5). The relatively modest isolated yield of $\mathbf{1 7 b}$ may be due to the volatility of this low molecular weight ester. The structure of $\mathbf{1 7} \mathbf{b}$ was confirmed by comparison of its ${ }^{1} \mathrm{H}$ NMR spectral data with the literature values. $\underline{16}$ While attempted decomplexation of $9 \mathbf{c}$ with CAN or $\mathrm{H}_{2} \mathrm{O}_{2} / \mathrm{HO}^{-}$gave a complex mixture of unidentified products, use of copper(II) chloride gave a low yield of 17c. We have previously observed that vinylcyclopropane carboxylates bearing an electron rich substituent are prone to secondary oxidation with CAN, $\underline{5 b}$ and this is the likely 
explanation for the low yields of 17c. The relative configuration of 17c was assigned based of its ${ }^{1} \mathrm{H}$ NMR spectral data. The signal for $\mathrm{H}-2$ appears at $\delta 3.60$ (dd) ppm; the smaller couplings ( 4.4 and $5.2 \mathrm{~Hz}$ ) are indicative of trans relative stereochemistry with respect to $\mathrm{H}-1$ and $\mathrm{H}-3$. In addition, the signal for $\mathrm{H}-4$ of 17c appears at $\delta 5.95-5.82 \mathrm{ppm}$, downfield of the signals for $\mathrm{H}-4$ of $\mathbf{1 7 a}(\delta 5.55 \mathrm{ppm})$ and $\mathbf{1 7 b}(\delta 5.44 \mathrm{ppm})$. This further downfield shift is attributed to the deshielding effect of the cis-ester substituent.

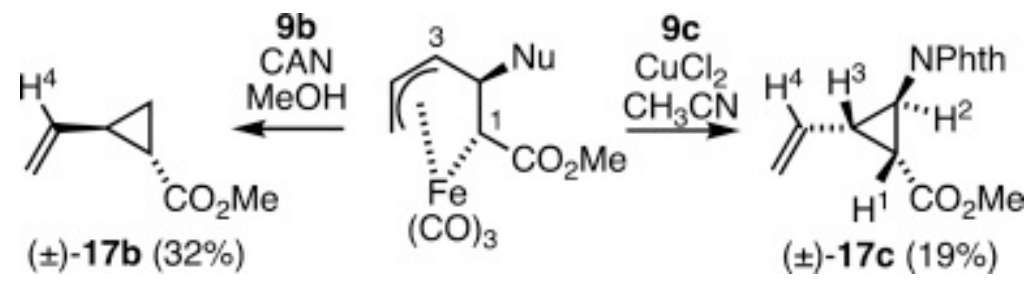

Scheme 5. Oxidative decomplexation of $\mathbf{9 b}$ and $\mathbf{9 c}$.

The vinylcyclopropane carboxylates $17 \mathbf{a}$ and $\mathbf{b}$ are the result of an oxidatively inducedreductive elimination which is known to occur with retention of configuration. The product 17c is the product from apparent inversion of configuration at $\mathrm{C} 3$ of 9c. This is rationalized on the basis of a rapid $\pi$-to- $\sigma$-to- $\pi$ rearrangement of the oxidized pentenediyl $\mathbf{2 2}$ to $\mathbf{2 3}$ prior to reductive elimination (Scheme 6). $\underline{5 c}$ The steric repulsion inherent in the gauche relationship between C4 and the phthalimide substituent in $\mathbf{2 2}$ is relieved in 23, where these two groups are anti. Reductive elimination from $\mathbf{2 3}$ to afford $\mathbf{1 7 c}$ occurs more rapidly than reductive elimination from 22.

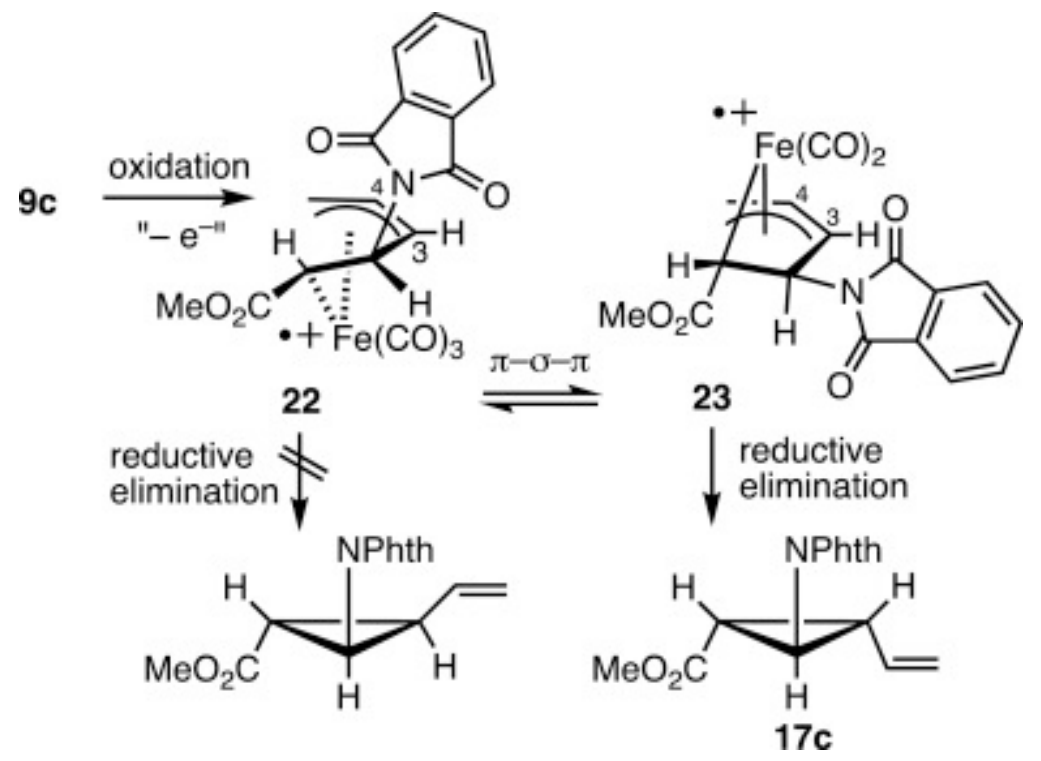

Scheme 6. Rationale for formation of $\mathbf{1 6 c}$.

Copper-catalyzed azide acetylene coupling (CU-ACC) reactions of ferrocenylmethyl azides has been reported,,$\underline{17}$ including the "labelling" of estradiol with a redox active organometallic functionality.17(a), 17(b), 17(c) In addition, estradiol complexes of metal carbonyls have been 
previously prepared for $\mathrm{Cr}, \mathrm{Mo}, \mathrm{W}, \mathrm{Mn}, \mathrm{Re}, \mathrm{Ru}$, and $\mathrm{Co}$ as both tracers for the steroid in biological systems by FT IR, and as radiopharmaceuticals (TC)..$\underline{18}$ While there have been a number of (5-azido-1,3-cyclodiene)iron complexes reported, 19 to our knowledge there are no reports of $\mathrm{Cu}$-ACC reactions from these azides. The reaction of dienyl azide $\mathbf{1 4 e}$ with terminal alkynes 24a-e, in the presence of copper(I) iodide, gave the (dienyl)triazoles 25a-e in moderate isolated yield (eqn. (2)). The 1,4-substituent pattern about the triazole ring of 20a-e was assigned on the basis of their NMR spectral data. In particular, a signal in their ${ }^{13} \mathrm{C}$ NMR spectra in the range $\delta 119.2-121.0 \mathrm{ppm}$ was assigned to the $\mathrm{C5}^{\prime}$ carbon of the triazole ring. .20 These assignments are consistent with the formation of isomers of this type by Cu-catalyzed "click" reactions. $\underline{\underline{21}}$ The preparation of estradiol complex $25 \mathrm{e}$ represents another example of a metal carbonyl "labelled" steroid.

\section{Conclusions}

Addition of hydride, methyl lithium or phthalimide nucleophiles to (1methoxycarbonylpentadientyl)iron(1+) cations $\mathbf{7}$ and $\mathbf{8}$ proceeds via bond formation at the internal C-2 carbon to afford (pentenediyl)iron complexes. Oxidative decomplexation of (pentenediyl)iron complexes 9a-c affords vinylcyclopropane-carboxylates 17a-c, and (+)-17a was utilized in a synthesis of the $\mathrm{C} 9-\mathrm{C} 16$ segment of ambruticin. Alternatively, reaction of 7 with weak nucleophiles proceeds via the transoid form of the cation to afford ( $E, E$-diene)iron complexes $14 \mathrm{~d}$ and $\mathbf{e}$. The azidodienyl complex $14 \mathrm{e}$ expands the range of azides which undergo Huisgen [3+2] cycloadditions to generate organometallic functionalized triazoles.

\section{Experimental}

\subsection{General data}

All reactions involving moisture or air sensitive reagents were carried out under a nitrogen atmosphere in oven-dried glassware with anhydrous solvents. THF and ether were distilled from sodium/benzophenone. Purifications by chromatography were carried out using flash silica gel (32-63 $\mu$ ). NMR spectra were recorded on either a Varian Mercury+ $300 \mathrm{MHz}$ or a Varian Unitylnova $400 \mathrm{MHz}$ instrument. $\mathrm{CDCl}_{3}$ was purchased from Cambridge Isotope Laboratories. ${ }^{1} \mathrm{H}$ and ${ }^{13} \mathrm{C}$ NMR spectra were calibrated to $7.27 \mathrm{ppm}$ for residual $\mathrm{CHCl}_{3}$ and the central peak at $77.23 \mathrm{ppm}$ for $\mathrm{CDCl}_{3}$. Coupling constants are reported in $\mathrm{Hz}$. Elemental analyses were obtained from Midwest Microlabs, Ltd., Indianapolis, IN, and high-resolution mass spectra were obtained from the University of Nebraska Center for Mass Spectrometry and the COSMIC lab at Old Dominion University.

\subsection{Tricarbonyl(1-methoxycarbonyl-2-methyl-3-pentene-1,5-diyl)iron ( \pm )-9a}

To a solution of $( \pm)-7(1.640 \mathrm{~g}, 4.000 \mathrm{mmol})$ in $\mathrm{CH}_{2} \mathrm{Cl}_{2}(40 \mathrm{~mL}, 0.1 \underline{\mathrm{M}}$ soln) flame dried flask under $\mathrm{N}_{2}$ cooled to $-78{ }^{\circ} \mathrm{C}$, was added dropwise a solution of methyllithium in ether $(4.0 \mathrm{~mL}$, $1.6 \underline{\mathrm{M}}, 6.4 \mathrm{mmol}$ ) over a period of $10 \mathrm{~min}$. The reaction mixture was stirred at $-78^{\circ} \mathrm{C}$ for $1 \mathrm{~h}$. It was then quenched with saturated aqueous $\mathrm{NH}_{4} \mathrm{Cl}(100 \mathrm{~mL})$ and the mixture was slowly warmed to room temperature. The layers were separated and the aqueous layer was extracted 
with $\mathrm{CH}_{2} \mathrm{Cl}_{2}$. The combined organic layers were dried $\left(\mathrm{MgSO}_{4}\right)$ and concentrated. The crude brown residue was purified by chromatography $\left(\mathrm{SiO}_{2}\right.$, hexanes-ethyl acetate $\left.=40: 1\right)$ to give

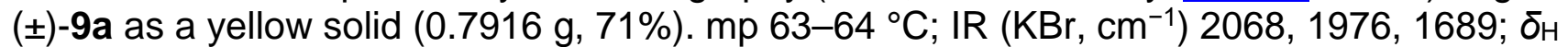
(300 MHz, CDCl 3 ) 4.58-4.44 (2H, m, H-3 and H-4), $3.67(3 \mathrm{H}, \mathrm{s}, \mathrm{OMe}), 3.59-3.52(1 \mathrm{H}, \mathrm{m}, \mathrm{H}-$ 5exo), 3.20-3.02 (1H, m, H-2), 2.50 (1H, dd, J 2.2, $11.0 \mathrm{~Hz}, \mathrm{H}-5$ endo), 0.70 (3H, d, J 7.5 Hz, $\mathrm{Me}), 0.00(1 \mathrm{H}, \mathrm{d}, \mathrm{J}$ 8.5, $\mathrm{H}-1)$; $\delta \mathrm{c}\left(75 \mathrm{MHz}, \mathrm{CDCl}_{3}\right) 211.0,210.6,203.9,180.8,97.3,67.6,54.2$, 51.5, 34.2, 25.8, 14.6. Anal. calcd for $\mathrm{C}_{11} \mathrm{H}_{12} \mathrm{O}_{5} \mathrm{Fe}: \mathrm{C}, 47.17$; $\mathrm{H}, 4.32$. Found: $\mathrm{C}$, 46.93; $\mathrm{H}$, $4.26 \%$.

\section{3. (1S)-Tricarbonyl(1-methoxycarbonyl-2-methyl-3-pentene-1,5-diyl)iron (-)-9a}

The reaction of (1S)-7 $(0.7490 \mathrm{~g}, 1.830 \mathrm{mmol})$ in $\mathrm{CH}_{2} \mathrm{Cl}_{2}$ at $-78{ }^{\circ} \mathrm{C}$ with an ethereal solution of methyl lithium $(2.013 \mathrm{mmol})$ was carried out in a fashion similar to the reaction of $( \pm)-7$ with methyl lithium. Purification of the crude product by chromatography $\left(\mathrm{SiO}_{2}\right.$, hexanes-ethyl acetate $=40: 1)$ to give $(-)-9 \mathrm{a}$ as a yellow solid $(0.2486 \mathrm{~g}, 49 \%) . \mathrm{mp} 66-67^{\circ} \mathrm{C} ;[\mathrm{\alpha}]_{\mathrm{D}} 23=-545(\mathrm{c}$ $0.252, \mathrm{CHCl}_{3}$ ). The ${ }^{1} \mathrm{H}$ and ${ }^{13} \mathrm{C} \mathrm{NMR}$ spectra for this product were identical to that for the racemic compound.

\subsection{Tricarbonyl(methyl 2E,4Z-heptadienoate)iron ( \pm )-10a}

To a solution of methyllithium $(2.0 \mathrm{~mL}, 1.4 \mathrm{M}$ in ether, $2.8 \mathrm{mmol})$ in THF $(15 \mathrm{~mL})$ and ether $(5 \mathrm{~mL})$ at $-78{ }^{\circ} \mathrm{C}$ was added $\mathrm{CuBr} \cdot \mathrm{Me}_{2} \mathrm{~S}(200 \mathrm{mg}, 0.972 \mathrm{mmol})$. The mixture was stirred for $45 \mathrm{~min}$, and then solid $( \pm)-7(200 \mathrm{mg}, 0.487 \mathrm{mmol})$ was added in one portion. The mixture was stirred for an additional $2 \mathrm{~h}$ at $-78^{\circ} \mathrm{C}$, then quenched with saturated aqueous $\mathrm{NH}_{4} \mathrm{Cl}(20 \mathrm{~mL})$ and the mixture was slowly warmed to room temperature. The resultant mixture was extracted several times with ether and the combined organic extracts were washed with brine, dried $\left(\mathrm{MgSO}_{4}\right)$ and concentrated. The residue was purified by column chromatography $\left(\mathrm{SiO}_{2}\right.$, hexanes-ethyl acetate $=3: 1)$ to afford $( \pm)$-10b as a yellow oil $(80 \mathrm{mg}, 58 \%)$. $\delta_{\mathrm{H}}(300 \mathrm{MHz}$, $\left.\mathrm{CDCl}_{3}\right) 6.02(1 \mathrm{H}, \mathrm{dd}, J 5.1,8.1 \mathrm{~Hz}, \mathrm{H}-3), 5.26(1 \mathrm{H}, \mathrm{dd}, J 5.4,7.8 \mathrm{~Hz}, \mathrm{H}-4), 3.64(3 \mathrm{H}, \mathrm{s}, \mathrm{OMe})$, $2.73(1 \mathrm{H}, \mathrm{dt}, \mathrm{J} 6.3,7.6 \mathrm{~Hz}, \mathrm{H}-5), 2.14(1 \mathrm{H}, \mathrm{d}, \mathrm{J} 8.6 \mathrm{~Hz}, \mathrm{H}-2), 1.54(1 \mathrm{H}, \mathrm{m}, \mathrm{H}-6), 1.19(1 \mathrm{H}, \mathrm{m}, \mathrm{H}-$ 6'), $0.96(3 \mathrm{H}, \mathrm{t}, \mathrm{J} 7.2 \mathrm{~Hz}, \mathrm{Me}-7)$; $\delta_{c}\left(75 \mathrm{MHz}, \mathrm{CDCl}_{3}\right)$ 173.3, 92.5, 85.5, 63.9, 51.6, 45.7, 22.6, 17.4 .

\subsection{Reaction of $( \pm)-7$ with trimethylaluminum}

A solution of trimethylaluminum (1.22 mL, $2.0 \underline{\mathrm{M}}$ in toluene, $2.44 \mathrm{mmol}$ ) was added to $\mathrm{CH}_{2} \mathrm{Cl}_{2}$ $(6 \mathrm{~mL})$, and water (6.8 equiv) was added. The mixture was cooled to $-30{ }^{\circ} \mathrm{C}$ and solid $( \pm)-7$ (100 mg, $0.243 \mathrm{mmol}$ ) was added in one portion. The mixture was stirred for $2 \mathrm{~h}$, while warming to room temperature. The reaction mixture was quenched with water, extracted several times with ethyl acetate and the combined extracts were washed with water, dried $\left(\mathrm{MgSO}_{4}\right)$ and concentrated. The residue was purified by column chromatography $\left(\mathrm{SiO}_{2}\right.$, hexanes-ethyl acetate $=10: 1)$ to afford a mixture of $( \pm)-10$ a and $( \pm)-9 \mathbf{a}\left(3: 1\right.$ ratio by ${ }^{1} \mathrm{H} \mathrm{NMR}$, $40 \mathrm{mg}, 59 \%)$. 


\subsection{Reaction of $( \pm)-7$ with methyl tris(isopropoxy)titanium}

To a solution of $\mathrm{TiCl}(i-\mathrm{PrO})_{3}(1.71 \mathrm{~g}, 6.57 \mathrm{mmol})$ in dry ether $(20 \mathrm{~mL})$ at $-30^{\circ} \mathrm{C}$ was added a solution of methyllithium $(4.69 \mathrm{~mL}, 1.4 \mathrm{M}$ in ether, $6.56 \mathrm{mmol}$ ) and the mixture was warmed to $0{ }^{\circ} \mathrm{C}$ over $1 \mathrm{~h}$ period. The mixture was transferred by cannula to a flame-dried round bottom flask and the solvent evaporated. The residue was taken up in dry $\mathrm{CH}_{2} \mathrm{Cl}_{2}(10 \mathrm{~mL})$ and cooled to $-78{ }^{\circ} \mathrm{C}$. A solution of $7(200 \mathrm{mg}, 0.486 \mathrm{mmol})$ in dry $\mathrm{CH}_{2} \mathrm{Cl}_{2}(10 \mathrm{~mL})$ was slowly added by syringe. The mixture was warmed to room temperature and stirred for $18 \mathrm{~h}$. The mixture was quenched with methanol until effervescence ceased and then poured into ice water. The mixture was extracted several times with $\mathrm{CH}_{2} \mathrm{Cl}_{2}$ and the combined extracts washed with water, brine, dried $\left(\mathrm{MgSO}_{4}\right)$ and concentrated. The residue was purified by column chromatography $\left(\mathrm{SiO}_{2}\right.$, hexanes-ethyl acetate $\left.=10: 1\right)$ to afford a mixture of $( \pm)-\mathbf{1 0 a}( \pm)-\mathbf{9 a}(2: 1$ ratio by ${ }^{1} \mathrm{H}$ NMR, $\left.50 \mathrm{mg}, 36 \%\right)$.

\subsection{Dicarbonyl(1-methoxycarbonyl-2-methyl-3-pentene-1,5- diyl)(triphenylphosphine)iron ( \pm )-11a}

The reaction of $( \pm)-8(0.640 \mathrm{~g}, 0.994 \mathrm{mmol})$ with methyllithium in $\mathrm{CH}_{2} \mathrm{Cl}_{2}$ was carried out in a similar fashion to the reaction of 7 with methyl lithium. Purification of the residue gave $( \pm)-12 a$ $(9.1 \mathrm{mg}, 2 \%)$ followed by $( \pm)-11 \mathrm{a}(0.3362 \mathrm{~g}, 66 \%)$ both as yellow solids. 11a: $\mathrm{mp} 194-195{ }^{\circ} \mathrm{C}$; IR $\left(\mathrm{KBr}, \mathrm{cm}^{-1}\right) 1983,1933,1680,1433,1152 ; \delta_{\mathrm{H}}\left(300 \mathrm{MHz}, \mathrm{CDCl}_{3}\right) 7.44-7.28\left(15 \mathrm{H}, \mathrm{m}, \mathrm{PPh}_{3}\right)$, $4.31(1 \mathrm{H}, \mathrm{t}, \mathrm{J} 6.6 \mathrm{~Hz}, \mathrm{H}-3), 3.81-3.72(1 \mathrm{H}, \mathrm{m}, \mathrm{H}-3), 3.74(3 \mathrm{H}, \mathrm{s}, \mathrm{OMe}), 3.17(1 \mathrm{H}$, app q, J $7.7 \mathrm{~Hz}, \mathrm{H}-2), 2.57-2.49$ (1H, m, H-5exo), 2.35-2.25 (1H, m, H-5endo), 0.61 (3H, d, J 7.0 Hz, $\mathrm{Me}), 0.01(1 \mathrm{H}, \mathrm{dd}, \mathrm{J} 3.5,7.9 \mathrm{~Hz}, \mathrm{H}-1)$; $\delta_{\mathrm{c}}\left(75 \mathrm{MHz}, \mathrm{CDCl}_{3}\right) 218.1,217.9,182.4,133.4$ (d, Jc-p $28.0 \mathrm{~Hz}$ ), 132.9 (d, Jc-p $9.7 \mathrm{~Hz}$ ), 130.3, 128.6 (d, Jc-p $9.1 \mathrm{~Hz}$ ), 96.6, 66.1, 56.8, 51.3, 35.2, 25.6 (d, Jc-p $6.3 \mathrm{~Hz}$ ), 13.5 (d, Jc-p $15.5 \mathrm{~Hz}$ ). Anal. calcd for $\mathrm{C}_{28} \mathrm{H}_{27} \mathrm{O}_{4} \mathrm{PFe} \cdot 1 / 2 \mathrm{H}_{2} \mathrm{O}: \mathrm{C}, 64.26 ; \mathrm{H}, 5.39$. Found: C, 64.29; H, 5.28\%.

\subsection{Dicarbonyl(methyl 2E,4Z-heptadienoate)(triphenyl-phosphine)iron ( \pm )-12a}

The reaction of $( \pm)-8$ (314 $\mathrm{mg}, 0.487 \mathrm{mmol})$ with methyllithium-CuBr was carried out in a similar fashion to the reaction of 7 with $\mathrm{Me}_{2} \mathrm{CuLi}$. Purification of the residue by column chromatography $\left(\mathrm{SiO}_{2}\right.$, hexanes-ethyl acetate $\left.=10: 1\right)$ gave $( \pm)-\mathbf{1 2 a}$ as a yellow solid $(140 \mathrm{mg}$, $56 \%) . \delta_{\mathrm{H}}\left(300 \mathrm{MHz}, \mathrm{CDCl}_{3}\right) 7.52-7.32\left(15 \mathrm{H}, \mathrm{m}, \mathrm{PPh}_{3}\right), 5.87(1 \mathrm{H}, \mathrm{dd}, \mathrm{J} 5.4,7.6 \mathrm{~Hz}, \mathrm{H}-3), 4.28$ $(1 \mathrm{H}, \mathrm{br} \mathrm{m}, \mathrm{H}-4), 3.66(3 \mathrm{H}, \mathrm{s}, \mathrm{OMe}), 1.95(1 \mathrm{H}, \mathrm{br} \mathrm{d}, \mathrm{J} 8.4 \mathrm{~Hz}, \mathrm{H}-2), 1.75-1.45\left(2 \mathrm{H}, \mathrm{m}, \mathrm{CH}_{2}\right)$, $1.05(1 \mathrm{H}, \mathrm{m}, \mathrm{H}-5), 0.72(3 \mathrm{H}, \mathrm{t}, \mathrm{J} 7.5 \mathrm{~Hz}, \mathrm{Me}-7) ; \delta \mathrm{c}\left(75 \mathrm{MHz}, \mathrm{CDCl}_{3}\right) \delta 175.2,134.3$ (Jc-p $40 \mathrm{~Hz}$ ), 133.2 (Jc-p $9.7 \mathrm{~Hz}), 130.0,128.3$ (Jc-p 9.7 Hz), 89.2, 87.7, 65.3, 51.2, 40.1 (br), 31.5, 22.7 (JC-p $17 \mathrm{~Hz}), 17.5,14.1$.

\subsection{Tricarbonyl(1-methoxycarbonyl-3-pentene-1,5-diyl)iron ( \pm )-9b and Tricarbonyl(methyl 2E,4Z-hexadienoate)iron ( \pm )-10b}

To a solution/suspension of $( \pm)-7(500 \mathrm{mg}, 1.22 \mathrm{mmol})$ in THF $(30 \mathrm{~mL})$ at $0{ }^{\circ} \mathrm{C}$ was added portion wise, solid $\mathrm{NaBH}_{3} \mathrm{CN}(92 \mathrm{mg}, 1.46 \mathrm{mmol})$. The mixture was stirred at $0{ }^{\circ} \mathrm{C}$ for $2 \mathrm{~h}$. The 
reaction mixture was diluted with water and extracted several times with ether. The combined organic extracts were washed with brine, dried $\left(\mathrm{MgSO}_{4}\right)$ and concentrated. Analysis of the crude product by ${ }^{1} \mathrm{H}$ NMR spectroscopy indicated that this was a mixture of $\mathbf{9 b}$ and $\mathbf{1 0 b}$ (ca. $7: 1)$. Purification of the residue by column chromatography $\left(\mathrm{SiO}_{2}\right.$, hexanes-ethyl acetate $=10: 1)$ gave $( \pm)$-10b (38 mg, 12\%), followed by $( \pm)-9 b(252 \mathrm{mg}, 78 \%)$, both as yellow oils. $9 b$ solidified upon standing.

( \pm )-9b: mp 84-85 ${ }^{\circ} \mathrm{C}$; IR $\left(\mathrm{CH}_{2} \mathrm{Cl}_{2}, \mathrm{~cm}^{-1}\right) 2063,1989,1689 ; \delta_{\mathrm{H}}\left(300 \mathrm{MHz}, \mathrm{CDCl}_{3}\right) 4.57(1 \mathrm{H}, \mathrm{td}, \mathrm{J}$ 7.3, 12.0 Hz, H-4), $4.35(1 \mathrm{H}, \mathrm{m}, \mathrm{H}-3), 3.70-3.66(4 \mathrm{H}, \mathrm{m}$ and s, OMe and $\mathrm{H}-5 \mathrm{exo}), 3.04(1 \mathrm{H}, \mathrm{td}$, J 7.5, 14.6 Hz, H-2), 2.57 (1H, dd, J 2.0, $12.0 \mathrm{~Hz}, \mathrm{H}-5$ endo), 2.34 (1H, dddd, J 1.2, 3.2, 8.8, 14.6 Hz, H-2'), 0.15 (1H, dd, J 7.4, 8.7 Hz, H-1); $\delta \mathrm{c}\left(75 \mathrm{~Hz}, \mathrm{CDCl}_{3}\right) 211.4,210.9,204.1,181.7$, 98.9, 59.3, 53.1, 51.4, 25.2, -0.9; Anal. Calcd for $\mathrm{C}_{10} \mathrm{H}_{10} \mathrm{O}_{5} \mathrm{Fe}: \mathrm{C}, 45.15 ; \mathrm{H}, 3.79$. Found: $\mathrm{C}$, $44.74 ; \mathrm{H}, 3.76$.

( \pm )-10b: $\delta \mathrm{H}\left(300 \mathrm{MHz}, \mathrm{CDCl}_{3}\right) 6.04(1 \mathrm{H}$, ddd, J 1.2, 5.1, 8.4 Hz, H-3), $5.33(1 \mathrm{H}, \mathrm{dd}, \mathrm{J} 5.1$, $7.8 \mathrm{~Hz}, \mathrm{H}-4), 3.67(3 \mathrm{H}, \mathrm{s}, \mathrm{OMe}), 2.90(1 \mathrm{H}, \mathrm{qd}, \mathrm{J} 7.2,7.8 \mathrm{~Hz}, \mathrm{H}-5), 2.22(1 \mathrm{H}, \mathrm{d}, \mathrm{J} 8.1 \mathrm{~Hz}, \mathrm{H}-2)$, $1.17(3 \mathrm{H}, \mathrm{d}, \mathrm{J} 7.2 \mathrm{~Hz}, \mathrm{Me}-6)$; $\delta \mathrm{c}\left(75 \mathrm{~Hz}, \mathrm{CDCl}_{3}\right) \delta 174.3$ ( $\mathrm{CO}_{2} \mathrm{Me}$ ), 92.2 (C-3), 87.1 (C-4), 54.8 (OMe), 51.7, 46.0, 14.4 (Me-6).

\subsection{Dicarbonyl(1-methoxycarbonyl-3-pentene-1,5-diyl)(triphenylphosphine)iron ( \pm )-11b}

The reaction of $( \pm)-8(500 \mathrm{mg}, 0.775 \mathrm{mmol})$ with $\mathrm{NaBH}_{3} \mathrm{CN}(58 \mathrm{mg}, 0.92 \mathrm{mmol})$ in THF at $0{ }^{\circ} \mathrm{C}$ was carried out in a fashion similar to the reaction of 7 with $\mathrm{NaBH}_{3} \mathrm{CN}$. Purification of the residue by column chromatography $\left(\mathrm{SiO}_{2}\right.$, hexanes-ethyl acetate $\left.=10: 1\right)$ gave $( \pm)-\mathbf{1 2 b}(20 \mathrm{mg}$, $5 \%)$ followed by ( \pm )-11b as a yellow solid (339 mg, 87\%). 11b: $\delta_{\mathrm{H}}\left(300 \mathrm{MHz}, \mathrm{CDCl}_{3}\right) 7.50-7.20$ $\left(15 \mathrm{H}, \mathrm{m}, \mathrm{Ph}_{3} \mathrm{P}\right), 4.13(1 \mathrm{H}, \mathrm{m}, \mathrm{H}-3), 3.83(1 \mathrm{H}, \mathrm{m}, \mathrm{H}-4), 3.75(3 \mathrm{H}, \mathrm{s}, \mathrm{OMe}), 3.08(1 \mathrm{H}, \mathrm{td}, \mathrm{J} 7.2$, 14.1 Hz, H-2), $2.66(1 \mathrm{H}, \mathrm{m}, \mathrm{H}-5 \mathrm{exo}), 2.35\left(2 \mathrm{H}, \mathrm{m}, \mathrm{H}-5\right.$ endo and $\left.\mathrm{H}-2^{\prime}\right), 0.17(1 \mathrm{H}, \mathrm{m}, \mathrm{H}-1) ; \delta \mathrm{c}$ $\left(75 \mathrm{MHz}, \mathrm{CDCl}_{3}\right) 183.1,133.4,132.8\left(J_{P C} 9.8 \mathrm{~Hz}\right), 130.1,128.4\left(J_{P C} 8.5 \mathrm{~Hz}\right), 98.0\left(J_{P C} 2.4 \mathrm{~Hz}\right)$, 57.0, 55.6, 51.0, 26.5, -1.7; Anal. Calcd for $\mathrm{C}_{27} \mathrm{H}_{25} \mathrm{O}_{4} \mathrm{FeP}$ : C, 64.82; $\mathrm{H}, 5.04$. Found: C, 64.65; $\mathrm{H}, 5.05$.

\subsection{Tricarbonyl(1-methoxycarbonyl-2-phthalimido-3-pentene-1,5-diyl)iron ( \pm )-9c}

To a solution of $7(400 \mathrm{mg}, 0.910 \mathrm{mmol})$ in $\mathrm{CH}_{2} \mathrm{Cl}_{2}(10 \mathrm{~mL})$ and nitromethane $(3 \mathrm{~mL})$ was added solid potassium phthalimide $(214 \mathrm{mg}, 1.16 \mathrm{mmol})$. The mixture was stirred for $18 \mathrm{~h}$, and then poured into water and the resulting mixture extracted several times with $\mathrm{CH}_{2} \mathrm{Cl}_{2}$. The combined extracts were washed with brine, dried $\left(\mathrm{Na}_{2} \mathrm{SO}_{4}\right)$ and concentrated. The residue was purified by chromatography $\left(\mathrm{SiO}_{2}\right.$, hexanes-ethyl acetate $\left.=4: 1\right)$ to give $9 \mathrm{c}$ as a yellow solid (242 mg, 65\%). mp 150-151 ${ }^{\circ} \mathrm{C} ; \delta_{\mathrm{H}}\left(300 \mathrm{MHz}, \mathrm{CDCl}_{3}\right) 7.65-7.82(4 \mathrm{H}, \mathrm{m}, \mathrm{Phth}), 5.57(1 \mathrm{H}, \mathrm{dd}, \mathrm{J}$ 7.3, $10.2 \mathrm{~Hz}, \mathrm{H}-2), 4.83(1 \mathrm{H}, \mathrm{ddd}, \mathrm{J} 7.2,9.0,12.3 \mathrm{~Hz}, \mathrm{H}-4), 4.66(1 \mathrm{H}, \mathrm{t}, \mathrm{J} 7.2 \mathrm{~Hz}, \mathrm{H}-3), 3.68$ (3H, s, OMe), $3.63(1 \mathrm{H}$, br d, J 7.8 Hz, H-5exo), 3.50 (1H, dd, J 2.1, $12.3 \mathrm{~Hz}, \mathrm{H}-5$ endo), 1.53 $(1 \mathrm{H}, \mathrm{d}, \mathrm{J}=10.2 \mathrm{~Hz}, \mathrm{H}-1)$; $\delta \mathrm{c}\left(75 \mathrm{MHz}, \mathrm{CDCl}_{3}\right) 210.4,209.0,203.6,179.1,167.8,134.3,131.2$, 123.6, 123.4, 100.8, 64.4, 55.8, 51.7, 47.8, 17.6. Anal. calcd for $\mathrm{C}_{18} \mathrm{H}_{13} \mathrm{NO}_{7} \mathrm{Fe}: \mathrm{C}, 52.58 ; \mathrm{H}$, 3.19. Found: C, 52.78; $H, 3.24 \%$. 


\subsection{Tricarbonyl(methyl 6-methylsulfonamido-2E,4E-hexadienoate)iron ( \pm )-14d}

To a solution of methane sulfonamide $(36 \mathrm{mg}, 0.38 \mathrm{mmol})$ in $\mathrm{CH}_{2} \mathrm{Cl}_{2}(6 \mathrm{~mL})$ was added solid 7 (100 mg, $0.228 \mathrm{mmol}$ ). The mixture was stirred for $4 \mathrm{~h}$, evaporated to dryness, and the residue was dissolved in ethyl acetate and the organic solution was extracted with water. The organic layer was washed with brine, dried $\left(\mathrm{Na}_{2} \mathrm{SO}_{4}\right)$ and concentrated. The residue was purified by chromatography $\left(\mathrm{SiO}_{2}\right.$, hexanes-ethyl acetate $\left.=7: 3\right)$ to give $( \pm)$-14d as a yellow oil (80 $\mathbf{m g}$, $98 \%) . \delta_{\mathrm{H}}\left(300 \mathrm{MHz}, \mathrm{CDCl}_{3}\right) 5.85(1 \mathrm{H}, \mathrm{dd}, J 5.1,8.0 \mathrm{~Hz}, \mathrm{H}-3), 5.40(1 \mathrm{H}, \mathrm{dd}, J 5.1,8.1 \mathrm{~Hz}, \mathrm{H}-4)$,

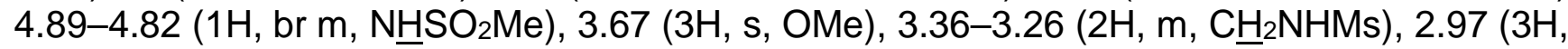
$\left.\mathrm{s}, \mathrm{SO}_{2} \mathrm{Me}\right), 1.32-1.22(1 \mathrm{H}, \mathrm{m}, \mathrm{H}-5), 1.11(1 \mathrm{H}, \mathrm{d}, \mathrm{J} 8.2 \mathrm{~Hz}, \mathrm{H}-2) ; \delta \mathrm{c}\left(75 \mathrm{MHz}, \mathrm{CDCl}_{3}\right) 172.5$, 86.5, 86.0, 58.6, 52.1, 46.9, 46.3, 41.2. HRMS (FAB): $\mathrm{M}+\mathrm{H}^{+}$, found 359.9837. $\mathrm{C}_{11} \mathrm{H}_{14} \mathrm{NO}_{7} \mathrm{SFe}$ requires 359.9840 .

\subsection{Tricarbonyl(methyl 6-azido-2E,4E-hexadienoate)iron ( \pm )-14e}

To a solution of $7(205 \mathrm{mg}, 0.500 \mathrm{mmol})$ in dry $\mathrm{CH}_{2} \mathrm{Cl}_{2}(15 \mathrm{~mL})$ was added trimethylsilyl azide (86 mg, $0.75 \mathrm{mmol})$. The reaction was stirred overnight and then quenched with water. The mixture was extracted several times with $\mathrm{CH}_{2} \mathrm{Cl}_{2}$ and the combined extracts dried $\left(\mathrm{MgSO}_{4}\right)$ and concentrated. The residue was purified by chromatography $\left(\mathrm{SiO}_{2}\right.$, hexanes-ethyl acetate $=10: 1)$ to give $14 \mathrm{e}$ as a yellow oil $(85 \mathrm{mg}, 56 \%) . \delta_{\mathrm{H}}\left(300 \mathrm{MHz}, \mathrm{CDCl}_{3}\right) 5.86(1 \mathrm{H}$, ddd, $\mathrm{J}$ 0.9, 5.1, 8.1 Hz, H-3), 5.35 (1H, dd, J 5.1, 8.1 Hz, H-4), 3.67 (3H, s, OMe), 3.50-3.35 (2H, m, $\left.\mathrm{C}_{2} \mathrm{~N}_{3}\right), 1.27(1 \mathrm{H}, \mathrm{q}, \mathrm{J} 7.2 \mathrm{~Hz}, \mathrm{H}-5), 1.12(1 \mathrm{H}, \mathrm{dd}, \mathrm{J} 0.9,8.4 \mathrm{~Hz}, \mathrm{H}-2) ; \delta \mathrm{c}\left(75 \mathrm{MHz}, \mathrm{CDCl}_{3}\right)$ $172.3,86.1,85.1,56.3,53.9,52.0,46.8$.

\subsection{4. ( \pm )-Methyl $\left(1 S^{*}, 2 S^{*}, 3 R^{*}\right)$-2-ethenyl-3-methylcyclopropane-carboxylate $( \pm)-17$ a}

To a solution of $9 \mathrm{a}(418.6 \mathrm{mg}, 1.495 \mathrm{mmol})$ in anhydrous methanol $(15 \mathrm{~mL})$ was added solid ceric ammonium nitrate in portions of one equivalent every $10 \mathrm{~min}(4.084 \mathrm{~g}, 7.475 \mathrm{mmol}$ total) until no more starting material was observed by tlc. After addition was complete, the reaction mixture was stirred for an additional $1 \mathrm{~h}$ and then partitioned between water and $\mathrm{CH}_{2} \mathrm{Cl}_{2}$, and the aqueous layer was extracted several times with $\mathrm{CH}_{2} \mathrm{Cl}_{2}$. The combined layers were dried $\left(\mathrm{MgSO}_{4}\right)$ and concentrated. The crude oil was subjected to kugelrohr distillation to give $( \pm)-\mathbf{1 6 b}$ (177.1 mg, 85\%) as a volatile colorless oil. IR (neat, $\left.\mathrm{cm}^{-1}\right)$ 3085, 2954, 1728, 1635, 1442 , $1409,1309,1173,1069,919 ; \delta \mathrm{H}\left(300 \mathrm{MHz}, \mathrm{CDCl}_{3}\right) 5.55(1 \mathrm{H}, \mathrm{ddd}, \mathrm{J} 17.0,10.3,8.7 \mathrm{~Hz}, \mathrm{C} \underline{\mathrm{H}}=$ $\left.\mathrm{CH}_{2}\right), 5.22(1 \mathrm{H}, \mathrm{J} 16.9,1.6 .0 .6 \mathrm{~Hz}, \mathrm{CH}=\mathrm{CH} \in \underline{\mathrm{Hz}}), 5.11(1 \mathrm{H}, \mathrm{J} 10.3,1.6,0.6 \mathrm{~Hz}, \mathrm{CH}=\mathrm{CH} \in \mathrm{Hz})$, $3.67\left(3 \mathrm{H}, \mathrm{s}, \mathrm{OCH}_{3}\right), 2.14(1 \mathrm{H}$, ddd, J 9.6, 9.6, 4.7 Hz, H-3), 1.73-1.60 $(1 \mathrm{H}, \mathrm{m}, \mathrm{H}-2), 1.45(1 \mathrm{H}$, dd, J 4.7, $4.7 \mathrm{~Hz}, \mathrm{H}-1), 1.13\left(3 \mathrm{H}, \mathrm{d}, \mathrm{J} 6.4 \mathrm{~Hz}, \mathrm{CH}_{3}\right)$; $\delta \mathrm{c}\left(75 \mathrm{~Hz}, \mathrm{CDCl}_{3}\right) 174.1,134.2,117.2$, 52.0, 31.4, 28.8, 23.1, 12.8; HRMS (EI): $\left[\mathrm{M}-\mathrm{CH}_{3}\right]^{+}$found 125.1335. $\mathrm{C}_{7} \mathrm{H}_{9} \mathrm{O}_{2}$ requires 125.0602 .

\subsection{5. (+)-Methyl (1S,2S,3R)-2-ethenyl-3-methylcyclopropane-carboxylate (+)-17a}

The decomplexation of (-)-9a (0.4200 g, $1.500 \mathrm{mmol})$ with CAN $(4.282 \mathrm{~g}, 7.810 \mathrm{mmol})$ in methanol was carried out in a fashion similar to the decomplexation of $( \pm)-9 a$. Purification of the crude oil by kugelrohr distillation gave (-)-17a as a volatile colorless oil (0.1177 g, 56\%); 
$[\alpha]_{D}^{23}=+139\left(\mathrm{c} 0.294, \mathrm{CHCl}_{3}\right)$. The ${ }^{1} \mathrm{H}$ and ${ }^{13} \mathrm{C}$ NMR spectra for this product were identical to that for the racemic compound.

\subsection{6. (+)-Methyl (1S,2S,3R)-2-[(1E,3R)-4-[[(1,1-dimethylethyl)-diphenylsilyl]oxy]-3-methyl- 1-butenyl]-3-methylcyclopropane-carboxylate (+)-19a}

To a solution of (+)-17a (90.90 $\mathrm{mg}, 0.6492 \mathrm{mmol})$ and $(+)-18(1.8919 \mathrm{~g}, 5.8391 \mathrm{mmol})$ in $\mathrm{CH}_{2} \mathrm{Cl}_{2}(7.0 \mathrm{~mL})$ under $\mathrm{N}_{2}$ was added Grubbs' 2 nd generation catalyst $(27.7 \mathrm{mg}, 0.0326 \mathrm{mmol})$. The reaction mixture was heated at reflux for $30 \mathrm{~h}$, and then cooled and concentrated under a stream of $\mathrm{N}_{2}$. The residue was purified by column chromatography $\left(\mathrm{SiO}_{2}\right.$, hexanes-ethyl

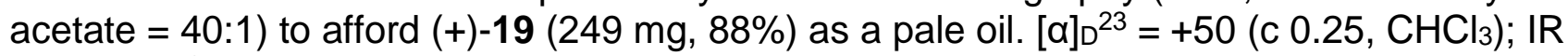
(neat, $\left.\mathrm{cm}^{-1}\right) 1728,1427,1313,1173,1112,824,702 ; \delta_{\mathrm{H}}\left(300 \mathrm{MHz}, \mathrm{CDCl}_{3}\right) 7.70-7.62(4 \mathrm{H}, \mathrm{m}$, ArH), 7.46-7.30 (6H, m, ArH), $5.54(1 \mathrm{H}, \mathrm{dd}, \mathrm{J}=7.3,15.5 \mathrm{~Hz}, \mathrm{H}-14), 5.15(1 \mathrm{H}, \mathrm{dd}, \mathrm{J}=8.5$, $15.8 \mathrm{~Hz}, \mathrm{H}-13)$, $3.16(3 \mathrm{H}, \mathrm{s}, \mathrm{OMe}), 3.51-3.46\left(2 \mathrm{H}, \mathrm{m}, \mathrm{CH}_{2} \mathrm{OSi}\right), 2.42-2.31(1 \mathrm{H}, \mathrm{m}, \mathrm{H}-15), 2.06$ $(1 \mathrm{H}, \mathrm{ddd}, \mathrm{J}=4.4,9.0,9.0 \mathrm{~Hz}, \mathrm{H}-12), 1.72-1.57(1 \mathrm{H}, \mathrm{m}, \mathrm{H}-11), 1.34(1 \mathrm{H}, \mathrm{dd}, \mathrm{J}=4.7,4.7 \mathrm{~Hz}, \mathrm{H}-$ 10), $1.10(3 \mathrm{H}, \mathrm{d}, J=6.4 \mathrm{~Hz}, \mathrm{Me}-28), 1.05(9 \mathrm{H}, \mathrm{s}, t-\mathrm{Bu}), 0.99$ (3H, d, J = 6.7 Hz, Me-27) (atom designation corresponding to ambruticin numbering, assignments were aided by COSY NMR); $\delta_{\mathrm{c}}\left(75 \mathrm{~Hz}, \mathrm{CDCl}_{3}\right) 174.1,136.2,135.7,133.9,129.6,127.7,125.4,68.8,51.9,39.8,30.9,28.8$, 27.1, 22.9, 19.6, 12.9; HRMS (FAB) M + Li ${ }^{+}$, found 443.2580. $\mathrm{C}_{27} \mathrm{H}_{36} \mathrm{O}_{3}$ SiLi requires 443.2594.

\subsection{Methyl trans-2-vinylcyclopropanecarboxylate $( \pm)-17 \mathrm{~b}$}

To a solution of $9 \mathbf{b}(130 \mathrm{mg}, 0.489 \mathrm{mmol})$ in anhydrous methanol $(10 \mathrm{~mL})$ at room temperature was added in one portion, solid ammonium cerium nitrate $(2.68 \mathrm{~g}, 4.89 \mathrm{mmol})$. The reaction mixture was stirred for $3 \mathrm{~h}$, poured into water and extracted several times with ethyl acetate. The combined extracts were washed with brine, dried $\left(\mathrm{MgSO}_{4}\right)$ and the solvent evaporated under reduced pressure. The residue was purified by chromatography $\left(\mathrm{SiO}_{2}\right.$, hexanes-ethyl acetate $=10: 1)$ to give $( \pm)-17 b$ as a volatile oil $(20 \mathrm{mg}, 32 \%) . \delta_{\mathrm{H}}\left(300 \mathrm{MHz}, \mathrm{CDCl}_{3}\right) 5.44(1 \mathrm{H}$, ddd, J 8.1, 10.2, $\left.18.3 \mathrm{~Hz}, \mathrm{CH}=\mathrm{CH}_{2}\right), 5.21\left(1 \mathrm{H}, \mathrm{dd}, \mathrm{J} 1.5,18.3 \mathrm{~Hz}, \mathrm{CH}=\mathrm{CH}_{\underline{\mathrm{H}} \mathrm{H}}\right), 5.04(1 \mathrm{H}$, dd, J 1.5, $\left.10.2 \mathrm{~Hz}, \mathrm{CH}=\mathrm{C} \mathrm{H}_{E} \mathrm{~Hz}\right), 3.72(3 \mathrm{H}, \mathrm{s}, \mathrm{OMe}), 1.70(1 \mathrm{H}, \mathrm{td}, \mathrm{J} 4.8,8.7 \mathrm{~Hz}, \mathrm{H}-1), 1.42(1 \mathrm{H}, \mathrm{td}, J$ 4.5, 8.7 Hz, H-2), 1.07-0.97 (2H, m, H-3 and $\left.\mathrm{H}^{3} 3^{\prime}\right)$; $\delta \mathrm{c}\left(75 \mathrm{MHz}, \mathrm{CDCl}_{3}\right)$ 171.0, 137.9, 114.8, $51.7,25.5,21.6,15.5$. The NMR spectral data for this compound is consistent with the literature values. $\underline{16}$

\subsection{Methyl 2-phthalimido-3-vinylcyclopropanecarboxylate ( \pm )-17c}

To a solution of $9 \mathbf{c}(80 \mathrm{mg}, 0.20 \mathrm{mmol})$ dissolved in anhydrous acetonitrile $(10 \mathrm{~mL})$ under nitrogen was added copper (II) chloride $(79 \mathrm{mg}, 0.59 \mathrm{mmol})$. The reaction mixture was heated at $50{ }^{\circ} \mathrm{C}$ for $1 \mathrm{~h}$ and then concentrated to remove acetonitrile. The residue was dissolved in $\mathrm{CH}_{2} \mathrm{Cl}_{2}$ and purified by column chromatography $\left(\mathrm{SiO}_{2}\right.$, hexanes-ethyl acetate $\left.=10: 1\right)$ to afford $( \pm)-17 \mathrm{c}$ as a colorless oil $(10 \mathrm{mg}, 0.037 \mathrm{mmol}, 19 \%) . \delta_{\mathrm{H}}\left(300 \mathrm{MHz}, \mathrm{CDCl}_{3}\right) 7.85-7.70(4 \mathrm{H}, \mathrm{m}$, Phth), 5.95-5.82 (1H, m, $\left.\mathrm{C} \underline{\mathrm{H}}=\mathrm{CH}_{2}\right), 5.43\left(1 \mathrm{H}\right.$, ddd, $\left.\mathrm{J} 0.6,1.8,17.2 \mathrm{~Hz}, \mathrm{CH}=\mathrm{CH}_{\underline{E}} \mathrm{~Hz}\right), 5.24$ $(1 \mathrm{H}, \mathrm{ddd}, \mathrm{J} 0.6,1.5,10.3 \mathrm{~Hz}, \mathrm{CH}=\mathrm{C} \underline{\mathrm{H}} \mathrm{Ez}), 3.75(3 \mathrm{H}, \mathrm{s}, \mathrm{OMe}), 3.60(1 \mathrm{H}, \mathrm{dd}, \mathrm{J} 4.4,5.2 \mathrm{~Hz}, \mathrm{H}-$ 2), 2.77-2.61 (2H, m, H-1 and $\mathrm{H}-3)$; $\delta_{\mathrm{c}}\left(100 \mathrm{MHz}, \mathrm{CDCl}_{3}\right)$ 210.0, 134.3, 131.7, 131.6, 123.4, 
119.0, 52.1, 35.1, 29.8, 26.4. HRMS (ESI): $\mathrm{M}_{2} \mathrm{Na}^{+}$, found 565.1588. $\left(\mathrm{C}_{15} \mathrm{H}_{13} \mathrm{NO}_{4}\right)_{2} \mathrm{Na}^{+}$requires 565.1581.

\subsection{9. (Tricarbonyl)(methyl 6-phenyl-1H-1,2,3-triazole-2E,4E-hexadienoate)iron ( \pm )-25a}

To a solution of $( \pm)-14 e(20 \mathrm{mg}, 0.065 \mathrm{mmol})$ in $\mathrm{CH}_{3} \mathrm{CN}(10 \mathrm{~mL})$ was added phenylacetylene (10 mg, $0.098 \mathrm{mmol})$ and copper (I) iodide $(2 \mathrm{mg}, 10 \mathrm{~mol} \%)$. The mixture was heated to $70{ }^{\circ} \mathrm{C}$ under nitrogen. After $19 \mathrm{~h}$, the temperature was raised to $100^{\circ} \mathrm{C}$ and the solution started to reflux. This temperature was maintained for another $5 \mathrm{~h}$. After cooling, the mixture was quenched with $\mathrm{H}_{2} \mathrm{O}$, extracted several times with $\mathrm{CH}_{2} \mathrm{Cl}_{2}$, and the combined organic extracts was washed with brine, dried $\left(\mathrm{Na}_{2} \mathrm{SO}_{4}\right)$ and concentrated. The residue was purified by column chromatography $\left(\mathrm{SiO}_{2}\right.$, hexanes-ethyl acetate gradient $=2: 1 \rightarrow$ pure ethyl acetate $)$ to afford $( \pm)-25 a(16 \mathrm{mg}, 0.039 \mathrm{mmol}, 60 \%)$ as a yellow oil. $\delta_{\mathrm{H}}\left(300 \mathrm{MHz}, \mathrm{CDCl}_{3}\right) 7.85-7.79(3 \mathrm{H}, \mathrm{m}, \mathrm{Ph}$ and triazole-H), 7.46-7.32 (3H, m, Ph), $5.91(1 \mathrm{H}$, ddd, J 0.9, 5.2, 8.6 Hz, H-3), $5.57(1 \mathrm{H}$, ddd, J 0.9, 5.2, 8.6 Hz, H-4), $4.60(1 \mathrm{H}$, dd, J 5.9, $14.6 \mathrm{~Hz}, \mathrm{H}-6), 4.48\left(1 \mathrm{H}, \mathrm{dd}, \mathrm{J}\right.$ 8.6, $\left.14.5 \mathrm{~Hz}, \mathrm{H}-6^{\prime}\right)$, $3.67(3 \mathrm{H}, \mathrm{s}, \mathrm{OMe}), 1.47-1.38(1 \mathrm{H}, \mathrm{m}, \mathrm{H}-5), 1.15(1 \mathrm{H}, \mathrm{dd}, \mathrm{J} 0.9,8.2 \mathrm{~Hz}, \mathrm{H}-2) ; \delta \mathrm{c}(75 \mathrm{MHz}$, $\left.\mathrm{CDCl}_{3}\right)$ 172.2, 148.3, 130.6, 129.1, 128.6, 126.0, 119.2, 86.3, 85.8, 55.3, 53.0, 52.0, 47.3. HRMS (ESI): $\mathrm{M}+\mathrm{Na}^{+}$, found 432.0250. $\mathrm{C}_{18} \mathrm{H}_{15} \mathrm{~N}_{3} \mathrm{O}_{5} \mathrm{FeNa}$ requires 432.0253 .

\subsection{0. (Tricarbonyl)(methyl 6-butyl-1H-1,2,3-triazole-2E,4E-hexadienoate)iron ( \pm )-25b}

The reaction of $( \pm)-14 e(20 \mathrm{mg}, 0.065 \mathrm{mmol})$ with 1-hexyne $(11 \mathrm{mg}, 0.13 \mathrm{mmol})$ in the presence of copper (I) iodide (2 $\mathrm{mg}, 10 \mathrm{~mol} \%$ ) was carried out in a fashion similar to the preparation of 25a. Purification of the residue by column chromatography $\left(\mathrm{SiO}_{2}\right.$, hexanes-ethyl acetate gradient $=2: 1 \rightarrow$ pure ethyl acetate $)$ gave $( \pm)-25 \mathrm{~b}(12 \mathrm{mg}, 0.031 \mathrm{mmol}, 48 \%)$ as a yellow oil. $\delta_{\mathrm{H}}\left(400 \mathrm{MHz}, \mathrm{CDCl}_{3}\right) 7.30(1 \mathrm{H}$, s, triazole-H), $5.89(1 \mathrm{H}$, dd, J 5.1, 8.3 Hz, H-3), 5.53 $(1 \mathrm{H}, \mathrm{dd}, \mathrm{J} 5.1,8.3 \mathrm{~Hz}, \mathrm{H}-4), 4.52-4.38\left(2 \mathrm{H}, \mathrm{m}, \mathrm{H}-6\right.$ and $\left.\mathrm{H}-6^{\prime}\right), 3.66(3 \mathrm{H}, \mathrm{s}, \mathrm{OMe}), 2.72(2 \mathrm{H}, \mathrm{t}, \mathrm{J}$ $\left.7.8 \mathrm{~Hz}, \mathrm{CH}_{2}\left(\mathrm{CH}_{2}\right)_{2} \mathrm{CH}_{3}\right), 1.69-1.60(4 \mathrm{H}, \mathrm{m}), 1.44-1.33\left(3 \mathrm{H}, \mathrm{m}, \mathrm{H}-5\right.$ and $\left.\mathrm{CH}_{2} \mathrm{CH}_{3}\right), 1.12(1 \mathrm{H}, \mathrm{d}$, J $8.3 \mathrm{~Hz}, \mathrm{H}-2), 0.93(3 \mathrm{H}, \mathrm{t}, J 7.4 \mathrm{~Hz}, \mathrm{Me}) ; \delta \mathrm{c}\left(75 \mathrm{MHz}, \mathrm{CDCl}_{3}\right)$ 172.2, 149.1, 120.3, 86.2, 85.7, 56.0, 52.8, 52.1, 47.1, 31.8, 25.5, 22.4, 13.9. HRMS (ESI): $\mathrm{M}+\mathrm{Na}^{+}$, found 412.0565.

$\mathrm{C}_{16} \mathrm{H}_{19} \mathrm{~N}_{3} \mathrm{O}_{5} \mathrm{FeNa}$ requires 412.0566 .

\subsection{1. (Tricarbonyl)[methyl 6-(4-ethynylphenyl)-1H-1,2,3-triazole-2E,4E-hexadienoate]iron $( \pm)-25 \mathrm{c}$}

The reaction of $( \pm)-14 \mathrm{e}(21 \mathrm{mg}, 0.068 \mathrm{mmol})$ with 1,4-diethynylbenzene $(9 \mathrm{mg}, 0.071 \mathrm{mmol})$ in the presence of copper (I) iodide (2 mg, $10 \mathrm{~mol} \%$ ) was carried out in a fashion similar to that for $25 \mathrm{a}$. The residue was purified by column chromatography $\left(\mathrm{SiO}_{2}\right.$, hexanes-ethyl acetate gradient $=2: 1 \rightarrow$ pure ethyl acetate) to afford $( \pm)-25 \mathrm{c}(12 \mathrm{mg}, 0.028 \mathrm{mmol}, 41 \%)$ as a yellow oil. $\delta_{\mathrm{H}}\left(400 \mathrm{MHz}, \mathrm{CDCl}_{3}\right) 7.82-7.77(3 \mathrm{H}, \mathrm{m}, \mathrm{ArH}$ and triazole-H), 7.57-7.53 $(2 \mathrm{H}, \mathrm{m}, \mathrm{ArH}), 5.92$ (1H, ddd, J 0.8, 5.0, 8.2 Hz, H-3), $5.57(1 \mathrm{H}, \mathrm{dd}, \mathrm{J} 5.1,8.2 \mathrm{~Hz}, \mathrm{H}-4), 4.63-4.45(2 \mathrm{H}, \mathrm{m}, \mathrm{H}-6$ and $\left.\mathrm{H}-6^{\prime}\right), 3.67(3 \mathrm{H}, \mathrm{s}, \mathrm{OMe}), 3.13(1 \mathrm{H}, \mathrm{s}, \mathrm{C} \equiv \mathrm{CH}), 1.44-1.37(1 \mathrm{H}, \mathrm{m}, \mathrm{H}-5), 1.15(1 \mathrm{H}, \mathrm{dd}, \mathrm{J} 0.8$, $8.2 \mathrm{~Hz}, \mathrm{H}-2)$; $\delta \mathrm{c}\left(100 \mathrm{MHz}, \mathrm{CDCl}_{3}\right) 171.9,147.4,132.7,130.7,125.6,122.0,119.3,86.0,85.6$, 83.4, 78.0, 55.0, 52.8, 51.9, 47.1. HRMS (ESI): $\mathrm{M}+\mathrm{Na}^{+}$, found 456.0252. $\mathrm{C}_{20} \mathrm{H}_{15} \mathrm{~N}_{3} \mathrm{O}{ }_{5} \mathrm{FeNa}$ requires 456.0253$]$. 


\subsection{2. (Tricarbonyl)methyl 6-[6-methoxy-2-naphthyl)-1H-1,2,3-triazole-2E,4E-}

hexadienoate)iron ( \pm )-25d

The reaction of $( \pm)-14 \mathrm{e}(20 \mathrm{mg}, 0.065 \mathrm{mmol})$ with 2-ethynyl-6-methoxy-naphthalene (18 $\mathrm{mg}$, $0.099 \mathrm{mmol})$ in the presence of copper (I) iodide $(2 \mathrm{mg}, 10 \mathrm{~mol} \%)$ was carried out in a fashion similar to the preparation of 25a. Purification of the residue by column chromatography $\left(\mathrm{SiO}_{2}\right.$, hexanes-ethyl acetate gradient $=2: 1 \rightarrow$ pure ethyl acetate $)$ gave $( \pm)-25 d(16 \mathrm{mg}, 0.033 \mathrm{mmol}$, $50 \%)$ as a yellow solid. mp $151-154{ }^{\circ} \mathrm{C} ; \delta_{\mathrm{H}}\left(400 \mathrm{MHz}, \mathrm{CDCl}_{3}\right) 8.25(1 \mathrm{H}, \mathrm{s}$, napthyl- $\mathrm{H}), 7.90$ $7.86(2 \mathrm{H}, \mathrm{m}$, napthyl- $\mathrm{H}$ and triazole- $\mathrm{H}), 7.80-7.76(2 \mathrm{H}, \mathrm{m}$, napthyl- $\mathrm{H}), 7.18-7.13(2 \mathrm{H}, \mathrm{m}$, napthyl-H), $5.91(1 \mathrm{H}$, ddd, J 1.2, 5.2, 8.1 Hz, H-3), $5.58(1 \mathrm{H}$, ddd, J 0.8, 5.1, 8.3 Hz, H-4), 4.65-4.45 (2H, m, H-6 and H-6'), $3.93(3 \mathrm{H}, \mathrm{s}, \mathrm{OMe}), 3.66(3 \mathrm{H}, \mathrm{s}, \mathrm{OMe}), 1.48-1.41(1 \mathrm{H}, \mathrm{m}, \mathrm{H}-$ 5), $1.16(1 \mathrm{H}, \mathrm{dd}, \mathrm{J}=1.2,8.0 \mathrm{~Hz}, \mathrm{H}-2)$; $\delta \mathrm{c}\left(100 \mathrm{MHz}, \mathrm{CDCl}_{3}\right) 172.1,158.0,148.4,134.5,129.7$, 129.0, 127.4, 125.6, 124.4, 119.4, 118.9, 105.8, 86.1, 85.6, 55.3, 52.8, 51.8, 47.0. HRMS (ESI): $\mathrm{M}+\mathrm{Na}^{+}$, found 512.0515. $\mathrm{C}_{23} \mathrm{H}_{19} \mathrm{~N}_{3} \mathrm{O}_{6} \mathrm{FeNa}$ requires 512.0515.

\subsection{3. (Tricarbonyl)methyl 6-[4-(3,17-dihydroxyestra-1,3,5(10)-trien-17-yl)-1H-1,2,3-} triazole-2E,4E-hexadienoate)iron 25e

The reaction of $( \pm)-14 \mathrm{e}(23 \mathrm{mg}, 0.074 \mathrm{mmol})$ with $17 \mathrm{a}$-ethynylestradiol $(33 \mathrm{mg}, 0.11 \mathrm{mmol})$ in the presence of copper (I) iodide ( $2 \mathrm{mg}, 10 \mathrm{~mol} \%$ ) was carried out in a fashion similar to the preparation of 25a. Purification of the residue by column chromatography $\left(\mathrm{SiO}_{2}\right.$, hexanes-ethyl acetate gradient $=2: 1 \rightarrow$ pure ethyl acetate $)$ gave $25 \mathrm{e}(16 \mathrm{mg}, 0.027 \mathrm{mmol}, 36 \%)$ as a yellow oil. This was determined to be a mixture of diastereomeric complexes by NMR spectroscopy. $\delta_{\mathrm{H}}\left(300 \mathrm{MHz}, \mathrm{CDCl}_{3}\right) 7.49$ and $7.47(1 \mathrm{H}, 2 \times \mathrm{s}$, triazole-H), $7.05(1 \mathrm{H}, \mathrm{d}, \mathrm{J} 8.4 \mathrm{~Hz}, \mathrm{ArH}), 6.63-$ $6.52(2 \mathrm{H}, \mathrm{m}, \mathrm{ArH}), 5.91(1 \mathrm{H}, \mathrm{dd}, \mathrm{J} 8.2,5.3 \mathrm{~Hz}, \mathrm{H}-3), 5.55(1 \mathrm{H}, \mathrm{dd}, \mathrm{J} 8.2,5.3 \mathrm{~Hz}, \mathrm{H}-4), 5.19(1 \mathrm{H}$, $\mathrm{s}, \mathrm{OH}), 4.51\left(2 \mathrm{H}, \mathrm{d}, \mathrm{J} 7.0 \mathrm{~Hz}, \mathrm{H}-6\right.$ and $\left.\mathrm{H}^{-6} \mathbf{6}^{\prime}\right), 3.67(3 \mathrm{H}, \mathrm{s}, \mathrm{OMe}), 2.85-2.65(3 \mathrm{H}, \mathrm{m}), 2.50-2.35$ $(1 \mathrm{H}, \mathrm{m}), 2.22-2.06(2 \mathrm{H}, \mathrm{m}), 2.03-1.82(3 \mathrm{H}, \mathrm{m}), 1.64-1.29(8 \mathrm{H}, \mathrm{m}), 1.14(1 \mathrm{H}, \mathrm{d}, \mathrm{J} 8.2 \mathrm{~Hz}, \mathrm{H}-2)$, 1.05 (3H, s, Me-18), $0.73(1 \mathrm{H}, \mathrm{br} \mathrm{t}, \mathrm{J} 7.0 \mathrm{~Hz}) . \delta \mathrm{c}\left(75 \mathrm{MHz}, \mathrm{CDCl}_{3}\right)$ 172.3, 154.3, 153.7, 138.5, $132.7,126.7,121.0,115.5,112.9,86.2,85.7,82.8,55.7,53.0,52.2,48.6,47.5,47.3,43.4$, 39.7, 38.3, 33.1, 29.9, 27.5, 26.4, 23.6, 14.4. HRMS (ESI): $\mathrm{M}+\mathrm{Na}^{+}$, found 626.1558.

$\mathrm{C}_{30} \mathrm{H}_{33} \mathrm{~N}_{3} \mathrm{O}_{7} \mathrm{FeNa}$ requires 626.1560].

\section{Acknowledgments}

This work was supported by the National Institutes of Health (GM-42641), National Science Foundation ( $\underline{\mathrm{CHE}-0848870)}$ ) and NSF instrumentation grant ( $\mathrm{CHE}-0521323)$. High-resolution mass spectra were obtained at the Old Dominion University COSMIC facility.

\section{References}

1(a) R. Gree Synthesis (1989), pp. 341-355 (b) R. Gree, J.P. Lellouche L.S. Liebeskind (Ed.), Advances in Metal-organic Chemistry, vol. 4, JAI Press, Greenwich, CT (1995), pp. 129273 (c) C. Iwata, Y. Takemoto Chem Commun (1996), pp. 2497-2504 (d) W.A.

Donaldson Aldrichim Acta, 30 (1997), pp. 17-24 (e) L.R. Cox, S.V. Ley Chem Soc Rev, 27 (1998), pp. 301-314 (f) W.A. Donaldson Curr Org Chem, 4 (2000), pp. 837-868 (g) 
W.A. Donaldson, S. Chaudhury Eur J Org Chem (2009), pp. 3831-3843 (h) H.-J. Knoelker Third Manual M. Schosser (Ed.), Organometallics in Synthesis, John Wiley \& Sons, New Jersey (2013), pp. 545-776

2 T.S. Sorenson, C.R. Jablonski J Organomet Chem, 25 (1970), pp. C62-C66

3 Pathway A. (a) C. Tao, W.A. Donaldson J Org Chem, 58 (1993), pp. 2134-2143 (b) S. Li, W.A. Donaldson Synthesis (2003), pp. 2064-2068 (c) N. Kausch-Busies, B. Kater, J.M. Heudorfl, A. Prokop, H.G. Schmalz Eur J Org Chem (2011), pp. 1133-1139

4 Pathway B. (a) W.A. Donaldson, M. Ramaswamy Tetrahedron Lett, 30 (1989), pp. 1339-

1342 (b) M.A. Hossain, M.-J. Jin, W.A. Donaldson J Organomet Chem, 630 (2001), pp. 5-10

5 Pathway C:. (a) M. Laabassi, R. Gree Bull Soc Chim Fr, 129 (1992), pp. 151-156 (b) W.A. Donaldson, L. Shang, C. Tao, Y.K. Yun, M. Ramaswamy, V.G. Young Jr. J Organomet Chem, 539 (1997), pp. 87-98 (c) Y.K. Yun, K. Godula, Y. Cao, W.A. Donaldson J Org Chem, 68 (2003), pp. 901-910 (d) L. Motiei, I. Marek, H.E. Gottlieb, V. Marks, J.-P. Lellouche Tetrahedron Lett, 44 (2003), pp. 5909-5912 (e) N.J. Wallock, W.A. Donaldson Org Lett, 7 (2005), pp. 2047-2049 (h) R.K. Pandey, S. Lindeman, W.A. Donaldson Eur J Org Chem (2007), pp. 3829-3831 (i) T.A. Siddiquee, J.M. Lukesh, S. Lindeman, W.A. Donaldson J Org Chem, 72 (2007), pp. 9802-9803

6 (a) J. Morey, D. Gree, P. Mosset, L. Toupet, R. Gree Tetrahedron Lett, 28 (1987), pp. 29592962 (b) P. Pinsard, J.-P. Lellouche, J.-P. Beaucourt, L. Toupet, L. Schio, R. Gree J Organomet Chem, 371 (1989), pp. 219-231 (c) W.A. Donaldson, L. Shang, M. Ramaswamy, C.A. Droste, C. Tao, D.W. Bennett Organometallics, 14 (1995), pp. 51195126

7 J.M. Lukesh, W.A. DonaldsonThe reactions of cation 7 with MeLi or MeLi/CuBr, the decomplexation of the (pentenediyl)iron complex $9 \mathrm{a}$ and the olefin crossmetathesis of (+)-17a to afford the C9-C16 segment of ambruticin were previously reported in communication form Chem Commun (2005), pp. 110-112

$\underline{8}$ For compounds which are racemic mixtures of enantiomers, only one enantiomer has been pictured for clarity.

9 CCDC 1537729 contains the supplementary crystallographic data for this paper. These data are provided free of charge by The Cambridge Crystallographic Data Centre.

10 J.T. Wasicak, R.A. Craig, R. Henry, B. Dasgupta, H. Li, W.A. Donaldson Tetrahedron, 53 (1997), pp. 4185-4198

11 (a) R.E. Lehmann, T.M. Bockman, J.K. Kochi J Am Chem Soc, 112 (1990), pp. 458-459 (b)

R.E. Lehmann, J.K. Kochi Organometallics, 10 (1991), pp. 190-202

12 D.W. Lee, C.F. Manful, J.R. Gone, Y. Ma, W.A. Donaldson Tetrahedron, 72 (2016), pp. 753-759

13 Y.K. Yun, H. Barmann, W.A. Donaldson Organometallics, 20 (2001), pp. 2409-2412

14 K. Konno, T. Fujishima, S. Maki, et al. J Med Chem, 43 (2000), p. 4247

15 S. Hanessian, T. Focken, X. Mi, et al. J Org Chem, 75 (2010), pp. 5601-5618 See references in this article for other syntheses of ambruticin

16 S. Ye, Z.Z. Huang, C.A. Xia, Y. Tang, L.X. Dai J Am Chem Soc, 124 (2002), pp. 2432-2433 
17 (a) E. Szanti-Pinter, J. Woulters, A. Gomory, et al. Steroids, 104 (2015), pp. 284-293 (b) E. Szanti-Pinter, Z. Csok, L. Kollar, K. Vekey, R. Skoda-Foldes J Organomet Chem, 718 (2012), pp. 105-107 (c) E. Szanti-Pinter, J. Balogh, Z. Csok, L. Kollar, A. Gomory, R. Skoda-Foldes Steroids, 76 (2011), pp. 1377-1382 (d) L. Kocsis, I. Szabo, S. Bosze, T. Jerni, F. Hudecz, A. Csampai Bioorg Med Chem Lett, 26 (2016), pp. 946-949 (e) S. Trakossas, E. Coutouli-Argyropoulou, D.J. Hadjipavlou-Litina Tetrahedron Lett, 52 (2011), pp. 1673-1676 (f) V.S. Sudhir, N.Y.P. Kumar, S. Chandrasekaran Tetrahedron, 66 (2010), pp. 1327-1334 (g) V.S. Sudhir, C. Venkateswarlu, O.T.M. Musthafa, S. Sampath, S. Chandrasekaran Eur J Org Chem (2009), pp. 2120-2129 (h) J.M. CasasSolvas, A. Vargas-Berenguel, L.F. Capitan-Vallvey, F. Santoyo-Gonzalez Org Lett, 6 (2004), pp. 3687-3690

18 (a) H. El Amouri, A. Vessieres, D. Vichard, S. Top, M. Gruselle, G. Jaouen J Med Chem, 35 (1992), pp. 3130-3135 (b) G. Jaouen, A. Vessieres, S. Top, M. Savignac, A.A. Ismail Organometallics, 6 (1987), pp. 1985-1987(c) D. Osella, O. Gambino, C. Nervi, E. Stein, G. Jaouen, A. Vessieres Organometallics, 13 (1994), pp. 3110-3114 (d) B. Ferber, S. Top, A. Vessieres, R. Welter, G. Jaouen Organometallics, 25 (2006), pp. 5730-5739 (e) L.G. Luyt, H.M. Bigott, M.J. Welch, J.A. Katzenellenbogen Bioorg Med Chem, 11 (2003), pp. 4977-4989 (f) S. Top, H. El Hafa, A. Vessieres, et al. J Am Chem Soc, 117 (1995), pp. 8372-8380 (g) S. Top, H. El Hafa, A. Vessieres, M. Huche, J. Vaissermann, G. Jaouen Chem Eur J, 8 (2002), pp. 5241-5249

19 (a) D.A. Brown, N.J. Fitzpatrick, W.K. Glass, P.K. Sayal Organometallics, 3 (1983), pp. 1137-1144 (b) A.J. Pearson, K. Srinivasan J Org Chem, 57 (1992), pp. 3965-3973 $\underline{20}$ X. Creary, A. Anderson, C. Brophy, Crowell, Z. Funk J Org Chem, 77 (2012) 8756-8751 21 V.V. Rostovtsev, L.G. Green, V.V. Fokin, K.B. Sharpless Angew Chem Int Ed, 41 (2002), pp. 2596-2599 